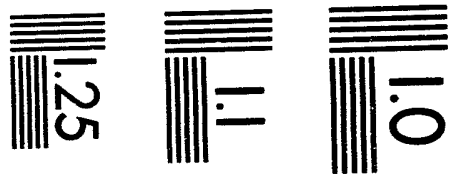

$$
\begin{aligned}
& \overline{\underline{\underline{\underline{\underline{N}}}}} \\
& \text { UII }
\end{aligned}
$$

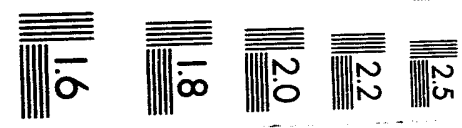



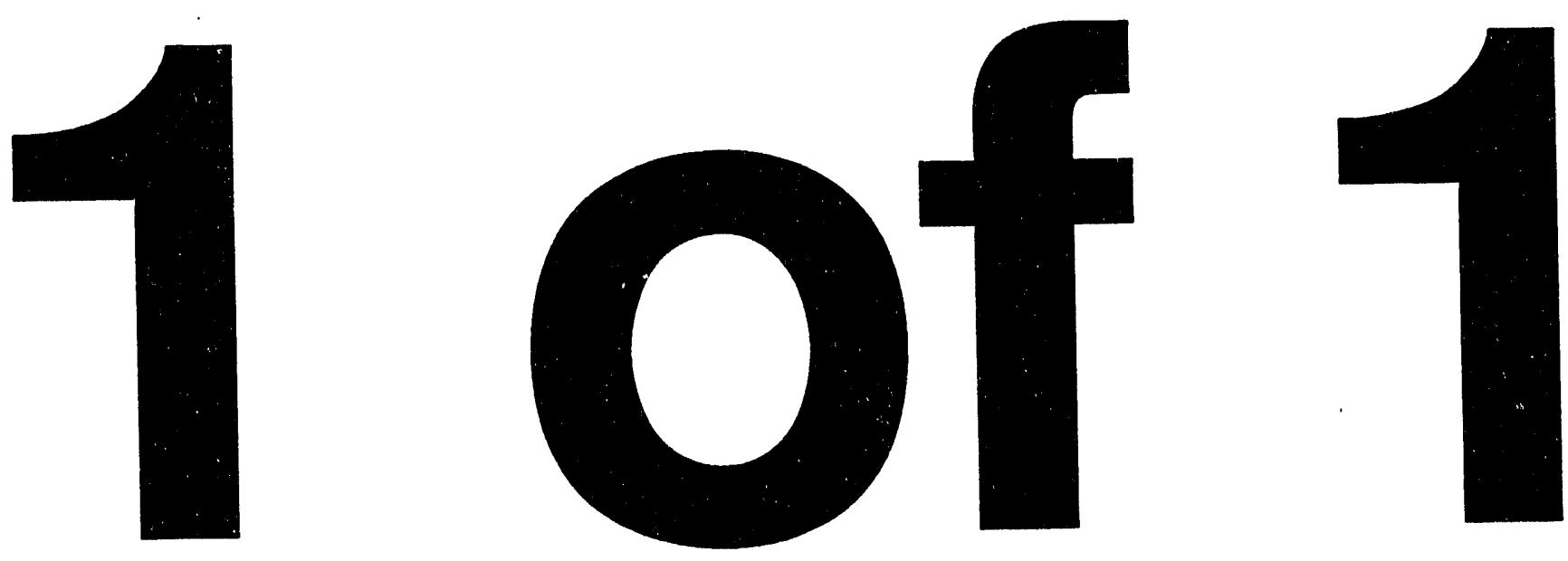


\title{
IDAHO CHEMICAL PROCESSING PLANT SPENT FUEL AND WASTE MANAGEMENT TECHNOLOGY DEVELOPMENT PROGRAM PLAN
}

\author{
Applied Technology Department \\ Niel Christiansen (Contact)
}

September 1993

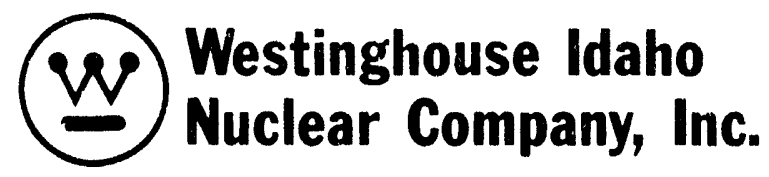

PREPARED FOR THE

DEPARTMENT OF ENERGY

IDAHO OPERATIONS OFFICE

UNDER CONTRACT DE AC07.84ID12435

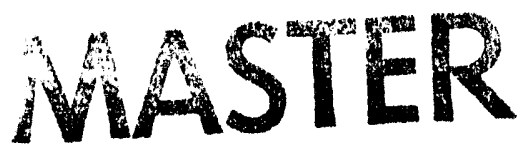




\section{TABLE OF CONTENTS}

LIST OF FIGURES $\ldots \ldots \ldots \ldots \ldots \ldots \ldots \ldots \ldots \ldots \ldots \ldots \ldots \ldots \ldots \ldots$

ACRONYMS $\ldots \ldots \ldots \ldots \ldots \ldots \ldots \ldots \ldots \ldots \ldots \ldots \ldots \ldots$

EXECUTIVE SUMMARY $\ldots \ldots \ldots \ldots \ldots \ldots \ldots \ldots \ldots \ldots$

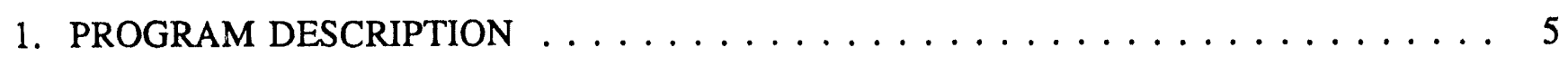

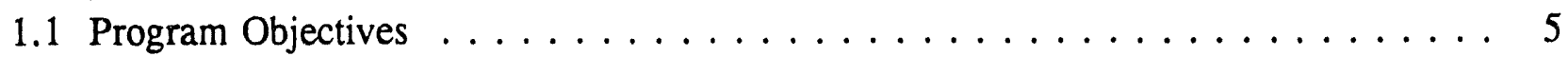

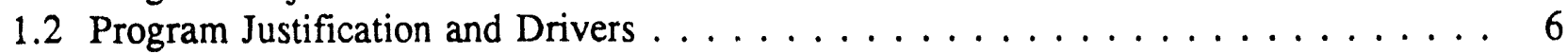

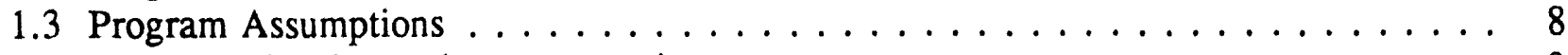

1.4 Program Planning and Documentation . . . . . . . . . . . . . 9

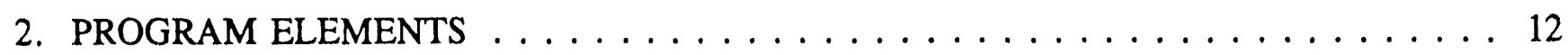

2.1 Major Program Elements . . . . . . . . . . . . . . . . . . . . . 12

2.1.1 Spent Nuclear Fuels Conditioning Process Development . . . . . . . . . . 12

2.1.2 Sodium-bearing Liquid Waste Conditioning Process Development . . . . . . . 13

2.1.3 Calcine Conditioning Process Development . . . . . . . . . . . . 13

2.1 .4 SNF Interim Storage . . . . . . . . . . . . . . . . . . . 14

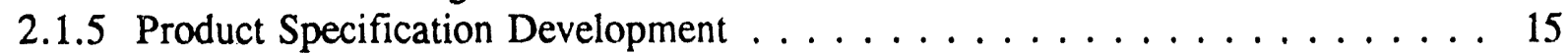

2.1.5.1 Waste Acceptance Criteria . . . . . . . . . . . . . . 15

2.1.5.2 Performance Assessment . . . . . . . . . . . . . 15

2.1.5.3 Waste Certification . . . . . . . . . . . . . . . 16

2.2 Waste Minimization Program Elements . . . . . . . . . . . . . . . 17

2.2 .1 Metal Recycle . . . . . . . . . . . . . . . . . . . . . . . 17

2.2.2 Decontamination and Decommissioning $\ldots \ldots \ldots \ldots \ldots \ldots \ldots$

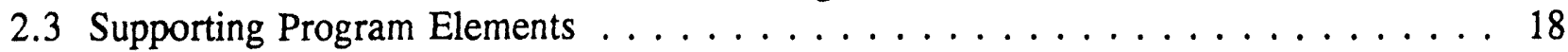

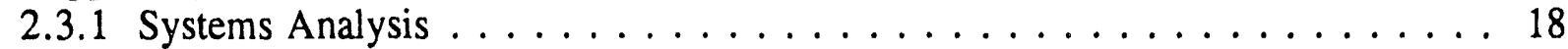

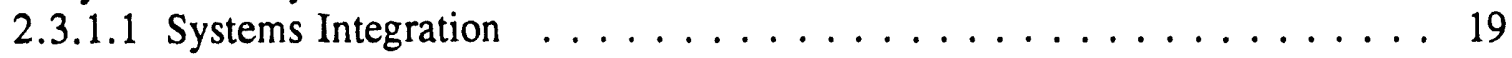

2.3.1.2 Systems Modeling . . . . . . . . . . . . . . . . 19

2.3.1.3 Performance Assessi ent . . . . . . . . . . . . . . 19

2.3.2 Stakeholder Interface . . . . . . . . . . . . . . . . . . . . 19

2.3 .3 Technology Transfer . . . . . . . . . . . . . . . . . . . . 20

2.3 .4 Facilities Support . . . . . . . . . . . . . . . . 20

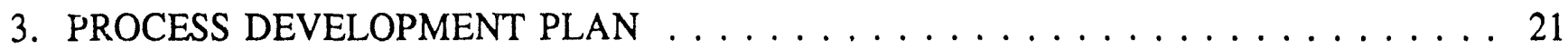

3.1 Identify Candidate Technologies and Processes . . . . . . . . . . . 22

3.1.1 Process Flowsheet Development . . . . . . . . . . . . . . . 22

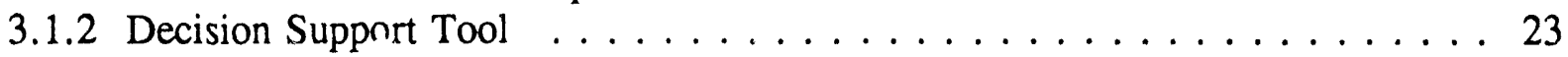

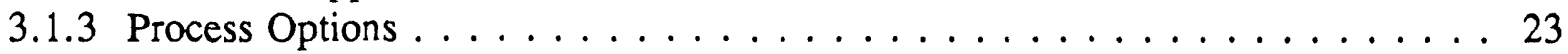

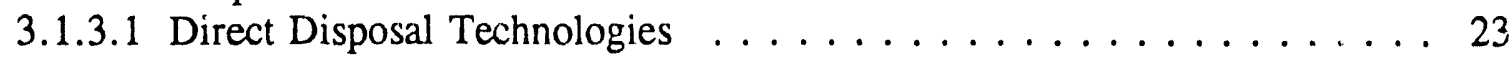

3.1.3.1.1 Multi-purpose Canister Development . . . . . . . . . 24

3.1.3.2 Conditioning/Waste Stabilization Technologies . . . . . . . . . . 24 
3.1.3.3 Separations 'Technologies . . . . . . . . . . . . . . 25

3.2 Select Candidate Processes for Evaluation . . . . . . . . . . . . . 33

3.2.1 Development Plans for Technologies . . . . . . . . . . . . . 33

3.3 Perform Detailed Evaluation of Candidate Processes . . . . . . . . . . . . . 33

3.4 Select Processes for Integrated Testing $\ldots \ldots \ldots \ldots \ldots \ldots \ldots \ldots \ldots \ldots$

3.5 Integrated Testing of Selected Processes . . . . . . . . . . . . . . . 34

3.6 Select Final Process . . . . . . . . . . . . . . . . . . . . . . . . 34

3.7 Process Implementation and Operational Facilities . . . . . . . . . . . . . . . 34

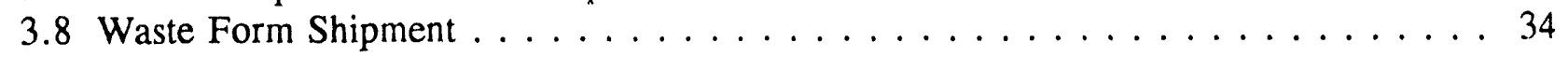

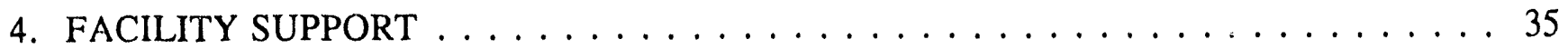

4.1 Laboratory-scale Tests . . . . . . . . . . . . . . . . . . . 35

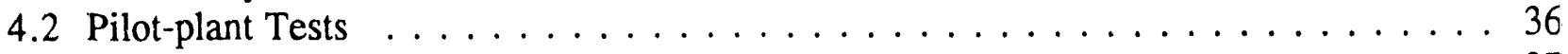

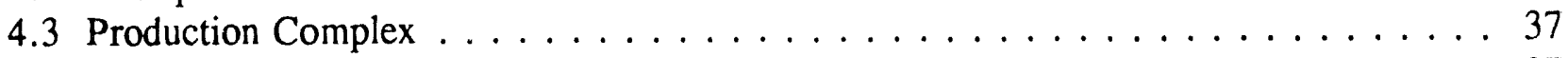

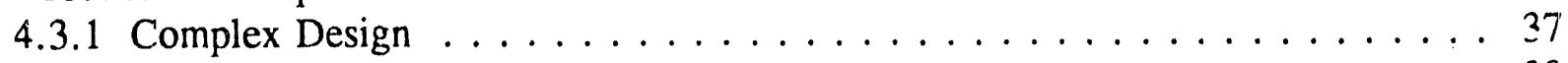

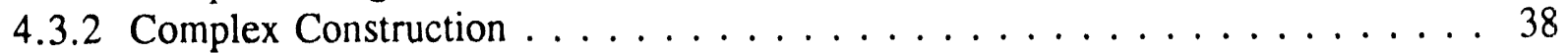

4.3 .3 Complex Operation . . . . . . . . . . . . . . . . . 38

4.4 Environmental Documentation and Permitting Strategies . . . . . . . . . . . 38

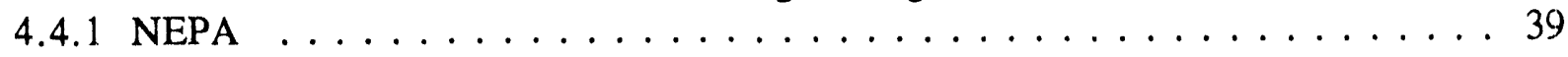

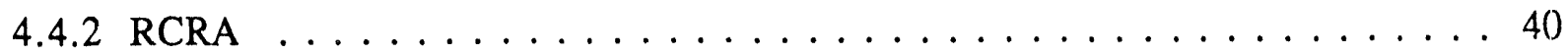

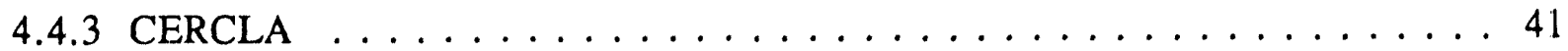

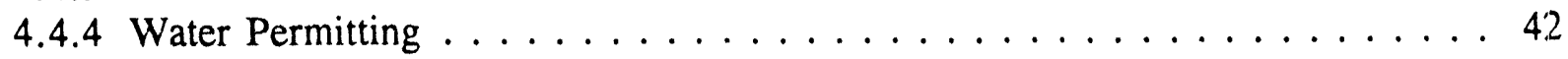

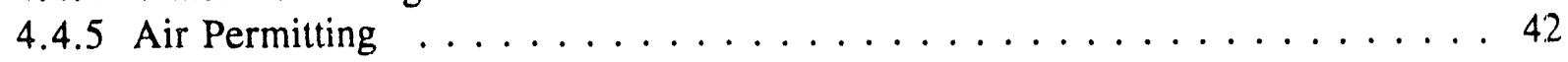




\section{LIST OF FIGURES}

Figures

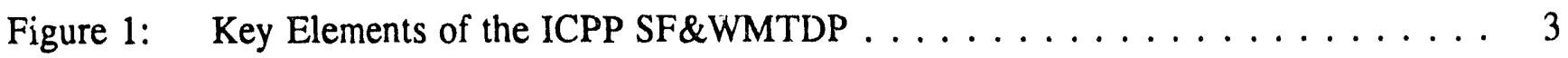

Figure 2: Process Development Plan $\ldots \ldots \ldots \ldots \ldots \ldots \ldots \ldots \ldots \ldots$

Figure 3: $\quad$ WINCO Planning Hierarchy $\ldots \ldots \ldots \ldots \ldots \ldots \ldots$

Figure 4: Hierarchy of ICPP SF\&WMTDP Documentation $\ldots \ldots \ldots \ldots \ldots \ldots$

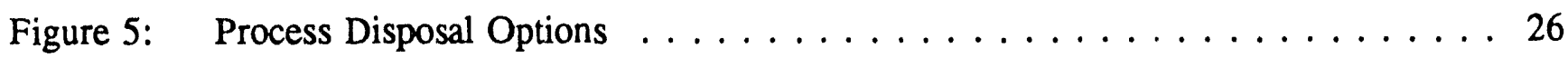

Figure 6: Process Flowsheet for Direct Disposal Process Option . . . . . . . . . . . . . . 29

Figure 7: Process Flowsheet for Conditioning Process Option . . . . . . . . . 30

Figure 8: Process Flowsheet for Aqueous Separations Process Option . . . . . . . . 31

Figure 9: Process Flowsheet for Pyrochemical Separations Process Option $\ldots \ldots \ldots \ldots 32$

Figure 10: $\quad$ NEPA Documentation Process $\ldots \ldots \ldots \ldots \ldots \ldots \ldots \ldots \ldots$ 


\section{ACRONYMS}

$\begin{array}{ll}\text { ADS } & \text { Activity Data Sheet } \\ \text { AEA } & \text { Atomic Energy Act } \\ \text { ALARA } & \text { As Low As Reasonably Achievable } \\ \text { ANL } & \text { Argonne National Laboratory } \\ \text { ANN } & \text { Aluminum Nitrate } \\ \text { APAQ } & \text { Air Permitting Applicability Questionnaire } \\ \text { BDAT } & \text { Best Demonstrated Available Technology } \\ \text { BRC } & \text { Below Regulatory Conccrn } \\ \text { BUD } & \text { Back-up Documentation } \\ \text { BWR } & \text { Boiling Water Reactor } \\ \text { CERCLA } & \text { Comprehensive Environmental Response, Compensation, and Liability Act } \\ \text { CFR } & \text { Code of Federal Regulations } \\ \text { CPP } & \text { Chemical Processing Plant (Idaho) } \\ \text { CX } & \text { Categorical Exclusion } \\ \text { DECOHA } & \text { Decontamination Hanulik (inventor of process) } \\ \text { DEQ } & \text { Division of Environmental Quality } \\ \text { DOE } & \text { Department of Energy } \\ \quad \text {-EM } & \text { Office of Environmental and Restoration Waste Management } \\ \quad-H Q & \text { Head-quarters } \\ \quad-I D & \text { Idaho Operations Office } \\ \quad-\text { OCRWM } & \text { Office of Civilian Radioactive Waste Management } \\ \text { DST } & \text { Decision Support Tool } \\ \text { EA } & \text { Environmental Assessment } \\ \text { EBS } & \text { Engineered Barrier System } \\ \text { EIS } & \text { Environmental Impact Statement } \\ \text { EPA } & \text { U.S. Environmental Protection Agency } \\ \text { ER\&WM } & \text { Environmental Restoration and Waste Management } \\ \text { FDP } & \text { Flourinel Dissolution Process } \\ \text { FFCA } & \text { Federal Facilities Compliance Act } \\ \text { FONSI } & \text { Finding of No Significant Impact } \\ \text { FPR } & \text { Fuel Processing Restoration } \\ \text { HEPA } & \text { High-efficiency Particulate Air (filter) } \\ \text { HFEF-N } & \text { Hot Fuel Examining Facility-North } \\ \text { HIP } & \text { Hot Isostatic Process } \\ \text { ELLW } & \text { High-level Liquid Waste } \\ \text { HLW } & \text { High-level Waste } \\ \text { HVAC } & \text { Heating, Ventilation, and Air Conditioning } \\ \text { ICPP } & \text { Idaho Chemical Processing Plant } \\ \text { IFR } & \text { Integral Fast Reactor } \\ \text { IFSF } & \text { Irradiated Fuel Storage Facility } \\ \text { INEL } & \text { Idaho National Engineering Laboratory } \\ \text { IRC } & \text { Idaho Research Center } \\ & \end{array}$




$\begin{array}{ll}\text { LDR } & \text { Land Disposal Restrictions } \\ \text { LLW } & \text { Low-level Waste } \\ \text { LWR } & \text { Light Water Reactor } \\ \text { MPC } & \text { Multi-purpose Canister } \\ \text { MPPF } & \text { Multi-functional Pilot Plant Facility } \\ \text { MT } & \text { Metric Ton } \\ \text { NEPA } & \text { National Environmental Policy Act } \\ \text { NESHAP } & \text { National Emission Standards for Hazardous Air Pollutants } \\ \text { NRC } & \text { U.S. Nuclear Regulatory Commission } \\ \text { NWCF } & \text { New Waste Calcining Facility } \\ \text { NWPA } & \text { Nuclear Waste Policy Act } \\ \text { PA } & \text { Performance Assessment } \\ \text { PB } & \text { Peach Bottom Reactor } \\ \text { PDF } & \text { Production Development Facility } \\ \text { PEW } & \text { Process Equipment Waste } \\ \text { PSD } & \text { Prevention of Significant Deterioration } \\ \text { PTC } & \text { Permit to Construct } \\ \text { PWAC } & \text { Preliminary Waste Acceptance Criteria } \\ \text { QA } & \text { Quality Assessment } \\ \text { RAL } & \text { Remote Analytical Laboratory } \\ \text { RCRA } & \text { Resource Conservation and Recovery Act } \\ \text { ROD } & \text { Record of Decision } \\ \text { RMW } & \text { Radioactive Mixed Waste } \\ \text { RSM } & \text { Radioactive Scrap Material } \\ \text { SA } & \text { Systems Analysis } \\ \text { SF\&WMTDP } & \text { Spent Fuel and Waste Management Technical Development Program } \\ \text { SNF } & \text { Spent Nuclear Fuel } \\ \text { SREX } & \text { Strontium Extraction } \\ \text { TAN } & \text { Test Area North } \\ \text { TDF } & \text { Technology Development Facility } \\ \text { THC } & \text { TAN Hot Cell } \\ \text { TRA } & \text { Test Reactor Area } \\ \text { TRUEX } & \text { Transuranic Extraction } \\ \text { TRW } & \text { Thompson-Ramo-Wooldridge (full names no longer used in Company name) } \\ \text { TSD } & \text { Treatment, Storage, and Disposal } \\ \text { WAC } & \text { Waste Acceptance Criteria } \\ \text { WAPS } & \text { Waste Acceptance Preliminary (or Product) Specifications } \\ \text { WA-SRD } & \text { Waste Acceptance-System Requirements Document } \\ \text { WINCO } & \text { Westinghouse Idaho Nuclear Company, Inc. } \\ \text { WMA } & \text { Waste Management Authority } \\ & \end{array}$




\section{EXECUTIVE SUMMARY}

The Department of Energy (DOE) has received spent nuclear fuel (SNF) at the Idaho Chemical Processing Plant (ICPP) for interim storage and reprocessing since 1953. Reprocessing of SNF has resulted in an existing inventory of 1.5 million gallons of radioactive sodium-bearing liquid waste and 3800 cubic meters $\left(\mathrm{m}^{3}\right)$ of calcine, in addition to the 768 metric tons (MT) of SNF and various other nuclear fuel materials in inventory. To date, the major activity of the ICPP has been the reprocessing of SNF to recover fissile uranium; however, recent changes in world events have diminished the demand to recover and recycle this material. As a result, DOE has discontinued reprocessing SNF for uranium recovery, making the need to properly manage and dispose of these and future materials a high priority.

In accordance with the Nuclear Waste Policy Act (NWPA) of 1982, as amended, disposal of SNF and high-level waste (HLW) is planned for a geologic repository. Preparation of SNF, HLW, and other radioactive wastes for disposal may include mechanical, physical, and/or chemical processes. This plan outlines the program strategy of the ICPP Spent Fuel and Waste Management Technology Development Program (SF\&WMTDP) to develop and demonstrate the technology required to ensure that SNF and radioactive waste will be properly stored and prepared for final disposal. The SF\&WMTDP will provide the technology development support necessary to meet the terms of the Department of Energy/Department of the Navy/State of Idaho agreement as ordered in the September 20,1993, modifications to the U.S. District Court's Opinion and Order of June 28, 1993. The program will be conducted in close coordination with the DOE Spent Nuclear Fuel Program, the ongoing complex-wide (i.e., all DOE sites) Environmental Impact Statement (EIS), and Federal Facilities Compliance Act (FFCA) efforts.

ICPP involvement in past DOE-owned SNF reprocessing efforts has resulted in successful technology flowsheet development, pilot-plants, demonstration facilities, and production facilities. In addition to the reprocessing of SNF, calcine technology has been developed and used to convert radioactive high-level liquid waste (HLLW) to a stable granular solid. Such activities demonstrate ICPP's experience and ability to perform the necessary research and development to implement the technologies required to successfully process SNF and radioactive waste.

The ICPP SF\&WMTDP consists of several technology development elements (see Figure 1), all of which support the goals of safe and efficient interim storage of SNF and radioactive waste, as well as the development of a process or processes to ultimately prepare the SNF and radioactive waste for final disposal. Program elements in support of acceptable interim storage and waste minimization include:

- developing and implementing improved radioactive waste treatment technologies;

- identifying and implementing enhanced decontamination and decommissioning techniques;

- developing radioactive scrap metal (RSM) recycle capabilities: and 
- developing and implementing improved technologies for the interim storage of SNF.

The program also establishes a systematic converging development plan that progresses from evaluation of candidate technologies to implementation of a final process(es) to prepare SNF and radioactive waste for final disposal (see Figure 2), and includes:

- performing a repository performance assessment to establish waste acceptance criteria and to direct technology development;

- identifying and evaluating new and existing technologies for implementation in waste and SNF disposition;

- $\quad$ characterizing waste forms;

- developing process flowsheets that will effectively and efficiently address all input streams and provide an optimal final product;

- identifying and planning facilities to support program testing, development, and conditioning; and

- applying a systems approach to improve understanding and resolution of programmatic issues, as well as to support informed strategic decision making.

This ICPP SF\&WMTDP Plan presents the key activities and decisions that must be completed to develop, demonstrate, and implement a process(es) that will properly prepare DOE-owned SNF and radioactive waste for safe and efficient interim storage and final disposal. This plan is intended to provide a planning basis to assure consistency and continuity within detailed planning, budgeting, and scheduling documents but does not specifically address funding levels, long-term schedules, or milestones. Such information is presented in associated budget and schedule documents. 


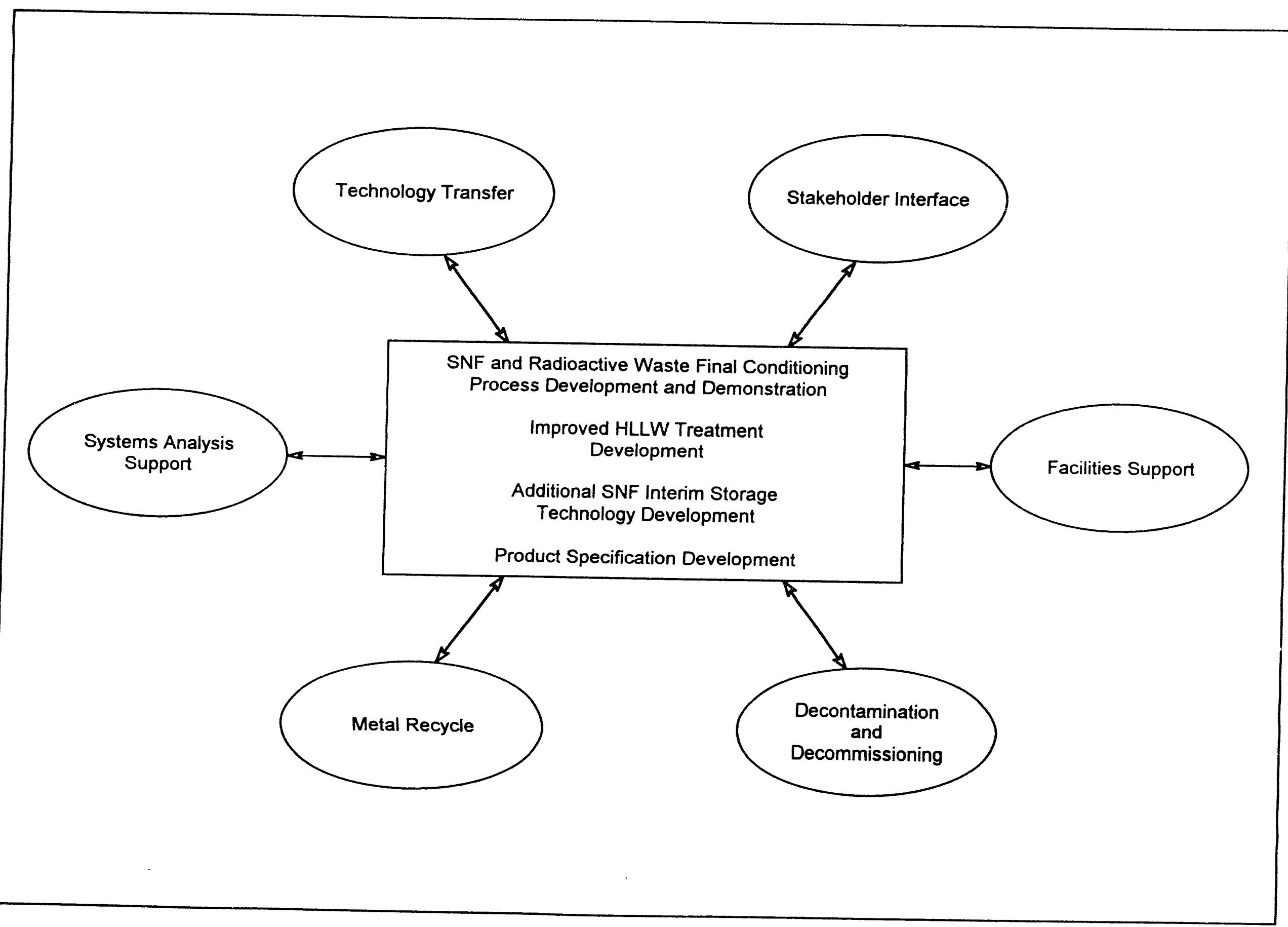

Figure 1: Key Elements of the ICPP SF\&WMTDP 


\begin{tabular}{|l|}
\hline Identify Candidate \\
Technologies and Processes \\
Headend/Pretreatment \\
- Retrieval \\
- BurningNoloxidation \\
- Mechanical Disassembly \\
- Dissolution \\
Fuel (Aqueous, Liquid Metal) \\
Calcine (Aqueous) \\
- Halide Volatility \\
(Chlorination) \\
- Calcination \\
- Oxidation/Reduction \\
Separations: \\
- Solvent Extraction \\
(CMP, CMPO, Amides, TBD, \\
Crown Ethers, Dicarbolides) \\
- Freeze Crystallization \\
- lon Exchange \\
(Organic, Inorganic) \\
- Supported Liquid Membranes \\
- VolatilizationDistillation \\
- Precipitation \\
- Fractional Condensation \\
- PyrochemicalPyrometallurgical \\
(Electorefining. Molten Salt \\
Extraction. Oxidation/Reduction, \\
Electrowinning) \\
- Off-gas Treatment \\
Stabilizattion/Packaging: \\
- Comentation/Grouting \\
- Glass \\
- Glass-ceramic \\
- Non-radioactive ANN Addition \\
- Canning \\
Final Disposition: \\
- Shallow Land Burial \\
- Monitored Retrievable Storage \\
- Mined Geologic Disposal Site \\
- Recycle \\
\hline
\end{tabular}

Activity 1

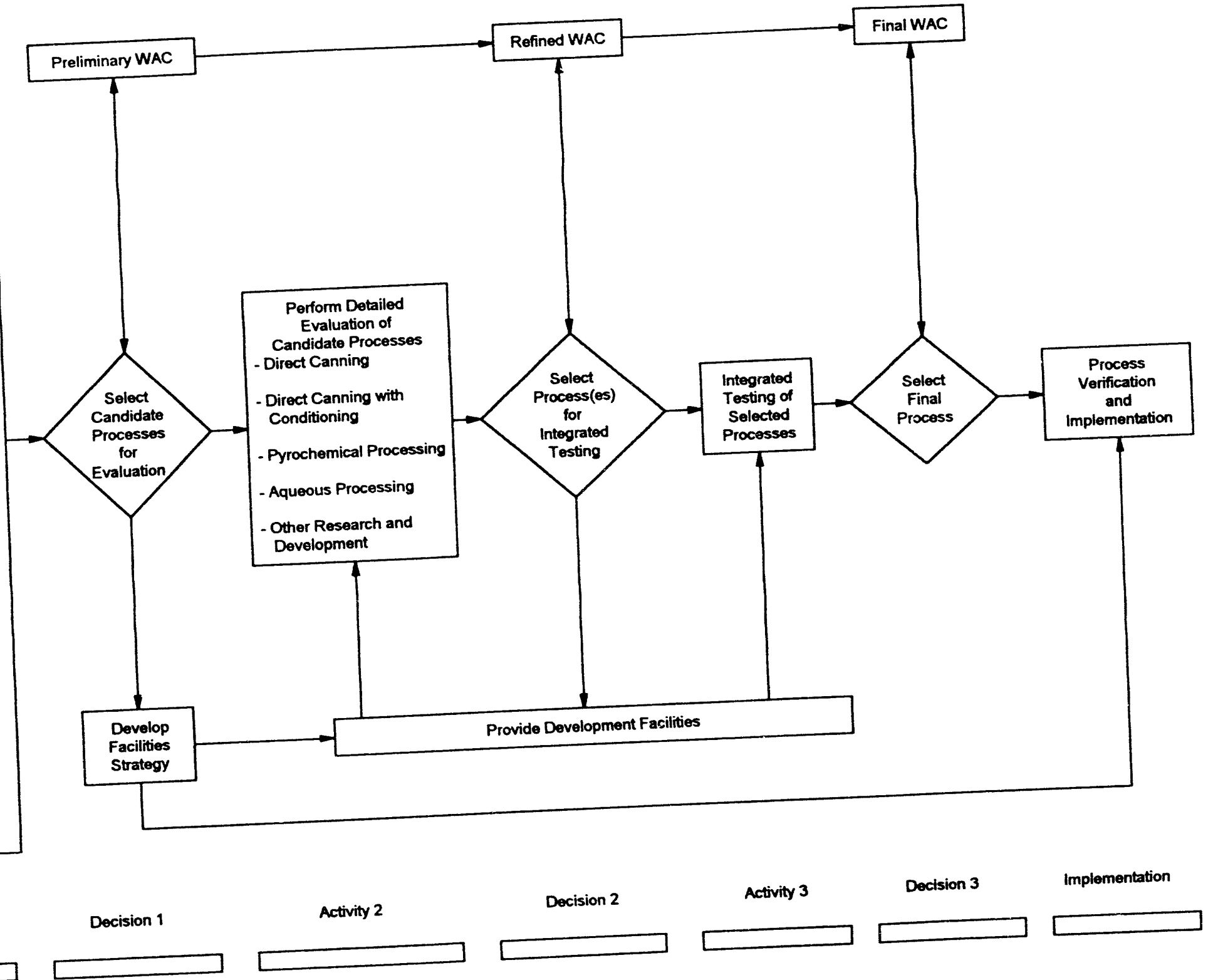

Figure 2: Process Development Plan 


\section{PROGRAM DESCRIPTION}

The Idaho National Engineering Laboratory (INEL) has operated nuclear facilities to support national interests for several decades, and, since 1953, has supported the development of technologies for the storage and reprocessing of SNF and the resultant wastes. The decision to discontinue reprocessing of SNF has left nearly $768 \mathrm{MT}$ of SNF in storage at the INEL with unspecified plans for future dispositioning. Additionally, approximately 1.5 million gallons of sodium-bearing HLLW and $3800 \mathrm{~m}^{3}$ of calcine are currently stored at the ICPP as a result of past reprocessing. These issues, along with increased environmental awareness within the DOE and among its contractors and stakeholders, mandate operation of existing and future facilities in an environmentally responsible manner and require satisfactory resolution of waste issues resulting from past activities. The Spent Fuel and Waste Management Technology Development Program (SF\&WMTDP) was initiated to implement existing technologies, as well as develop new technologies needed, to support storage, preparation, and ultimate disposition of present and future SNF and radioactive waste. Efforts will be made to utilize existing facilities to the extent practical in meeting SF\&WMTDP objectives.

\subsection{Program Objectives}

The primary objective of the SF\&WMTDP is to develop and demonstrate safe, costeffective, and environmentally responsible methods for the interim storage and final disposition of SNF and radioactive wastes. The program will, ultimately, select and implement technologies and processes that result in the conditioning and qualification of SNF and radioactive waste for permanent disposal. The program will also provide technical support to resolve current SNF and radioactive waste interim storage issue:, such as removal of sodium waste from the existing tank farm and removal of SNF from the CPP-603 basins. Success will be measured in terms of safety, stakeholder acceptance, cost, technical robustness, regulatory compliance, volume, time, and technical risk.

Emphasis will be placed on process robustness to assure that processes will apply not only to INEL SNF and radioactive waste but will also foster transfer of technologies to address the conditioning of a broad range of present and future SNF and radioactive wastes. The SF\&WMTDP will aggressively pursue all technology transfer opportunities via established mechanisms such as Cooperative Research and Development Agreements or, if appropriate, by negotiating innovative arrangements to suit the specialized needs of all interested parties. 


\subsection{Program Justification and Drivers}

The responsible pursuit of nuclear technologies to support national economic and defense interests demands a means of dispositioning the by-products of nuclear operations and the closing of the nuclear fuel cycle. A national policy has been established by the Nuclear Waste Policy Act (NWPA), which requires final disposal of SNF and sadioactive waste in accordance with U.S. Environmental Protection Agency (EPA) and Nuclear Regulatory Commission (NRC) standards. Until a final disposal site is available, additional interim storage will be required to accommodate SNF and to facilitate moving existing SNF and radioactive waste from aging facilities. As stated, the SF\&WMTDP will develop, demonstrate, and implement technologies for safe and efficient interim storage of SNF and radioactive waste and for the preparation and qualification of these materials for repository acceptance. This will enable safe and environmentally responsible storage and disposal of current inventories at the INEL and other DOE sites, thus closing the nuclear fuel cycle.

In light of these and other issues, Hazel O'Leary, Secretary of Energy; John H. Dalton, Secretary of the Navy; and Cecil B. Andrus, Governor of the State of Idaho, entered into an agreement on August 9, 1993, proposing modifications to the U.S. District Court's Opinion and Order of June 28, 1993. On September 20, 1993, Senior United States District Judge Harold L. Ryan issued an order ratifying the proposed modifications. As amended, DOE shall:

- $\quad$ accelerate the removal of the fuel from [the North, Middle, and South Basins of Building 603 at INEL's Chemical Processing Plant];"

- $\quad$ accelerate activities related to the treatment and disposal of high-level radioactive wastes stored at the INEL;"

- if determined that pillar and panel containment vaults do not meet seismic standards or other federal regulations, "use its best efforts to complete construction [of such replacement tanks] by the close of 1999 construction season" per the schedule outlined in the modification order; and

- $\quad$ "work with the State of Idaho and the Eastern Idaho Economic Development Council to join in a financial partnership with DOE's new INEL contractor to encourage regional economic development" (i.e., technology transfer, worker retraining, and local business development).

The ICPP currently stores SNF in both underwater and dry storage facilities. One of those facilities, CPP-603, consists of three underwater basins-North and Middle (built in 1951), and South (built in 1959) - and an adjoining dry storage facility called the Irradiated Fuel Storage Facility (IFSF), built in 1974. Due to the age of the basins and the deteriorating condition of several of the fuel elements stored therein, it is necessary to move all of the SNF out of CPP-603 basins to a newer underwater storage facility located in CPP-666, built 
in 1984. As ordered, DOE will move "all 662 units of spent nuclear fuel in [the] North and Middle Basins by December 31, 1996" and "all 718 units of spent nuclear fuel in [the] South Basin . . . by December 31, 2000." Additional relocation options include temporarily storing SNF that cannot be safely moved to CPP-666 in the South basin of CPP-603, or at either the IFSF or new dry storage facilities.

ICPP tank farm tanks currently contain approximately 1.5 million gallons of sodium-bearing liquid waste that cannot be calcined without being blended with either first-cycle raffinates from the reprocessing of SNF or with cold aluminum nitrate (ANN). Raffinates from past reprocessing will soon be depleted, and blending with cold ANN will significantly increase waste volume. As ordered, DOE will "identify a limited number of potential technologies to calcine or process sodium-bearing liquid waste on or before November 15, 1993" and "select a [final] technology for calcining or processing sodium liquid waste, in conjunction with the record of decision for the EIS [to be issued no later than June 1, 1995]." Additionally, the DOE will (1) "calcine all high-level liquid radioactive waste that does not contain sodium on or before January 1, 1998;" and (2) "calcine or otherwise process as much sodium-bearing high-level radioactive liquid waste . . . as DOE and the State of Idaho mutually agree is practicable by January 1, 1998." By developing alternative technologies for treating the sodium-bearing liquid wastes and/or enabling calcining without requiring cold additives, the SF\&WMTDP will support meeting the modifications to the District Court's Opinion and Order while following sound waste minimization management principles.

Related to these issues it has been determined that calcine generated after May 8, 1992 does not meet land disposal restrictions (LDR), since calcine is not the best demonstrated available technology (BDAT). To bring ICPP calcine into compliance with BDAT requirements, the SF\&WMTDP will develop and demonstrate technologies for further treatment of calcine and, in accordance with the schedule established by the September 20, 1993, order, "select a technology for converting calcined waste into an appropriate form for disposal in conjunction with the record of decision for the EIS [to be issued on or before June 1, 1995]." The Order further states that DOE shall "construct facilities necessary to implement the technologies selected for calcining or processing sodium liquid waste and for converting calcine waste . . . in accordance with a schedule to be negotiated with the State of Idaho."

The Federal Facilities Compliance Act (FFCA) requires DOE facilities to enter into binding agreements with their respective states as to how they will attain full compliance with all applicable regulations. An FFCA conceptual site treatment plan is currently being prepared which will include commitments for preparing DOE-owned SNF, sodium-bearing liquid waste, high-level liquid waste (HLLW), and calcine at the ICPP for final disposal. This SF\&WMTDP plan, while meeting recent Court Orders, will support FFCA commitments. At present, neither the tank farm vaults (secondary containment for tanks containing sodiumbearing liquid waste) nor the lines and valve boxes in the tank farm meet Resource Conservation and Recovery Act (RCRA) requirements for secondary containment. These noncompliance issues, along with seismic concerns regarding the panel and pillar construction of vaults on some of the earlier tanks, has resulted in a Notice of 
Noncompliance consent order from the State of Idaho which requires that tank farm tanks with panel and pillar vaults be out of service by 2009 , and that remaining tanks be out of service by 2015. Addressing these issues, the September 20, 1993 order states that if the June 1, 1995, Record of Decision for the INEL Environmental Restoration and Waste Management (ER\&WM) EIS "determines a need to construct replacement capacity for tanks containing high-level liquid radioactive wastes that do not meet seismic standards of other applicable legal requirements," DOE shall (1) "begin construction of such replacement tanks not later than the close of the [1996] construction season;" (2) "complete vault construction and initiate tank erection [no later than October 1, 1998]:" and (3) "use its best efforts to complete construction by the close of 1999 construction season, but in no event later that four . . . years after commencement of construction."

Successful development, integration, and implementation of technologies to meet U.S. District Court Orders and FFCA agreements, including the INEL ER\&WM EIS, will not only allow continued receipt of Naval and other DOE-owned SNF in full compliance with regulations and commitments, but will also afford many opportunities for technology transfer to private industry. Additionally, a successful SF\&WMTDP will provide the substance needed to earn stakeholder confidence enabling continued use of INEL facilities to receive and condition SNF in support of national interests.

\subsection{Program Assumptions}

The following assumptions have been made in developing this program plan:

- Processes must accommodate spent nuclear fuels (SNF) and two radioactive waste types: (1) Radioactive sodium-bearing and non sodium-bearing liquid wastes, and (2) Calcine.

- Processes should also be applicable to a broad range of SNF and waste issues at various DOE complexes.

- Existing facilities will be utilized to the extent practical.

- For disposition approaches involving constituent separation, actinides can be collected for engineered storage, and fission products and toxic materials will be collected into an HLW stream.

- Low-level waste (LLW) will meet NRC Class C limits.

A single waste form for HLW and LLW (i.e., glass-ceramic, glass, grout) will be produced. 
- $\quad$ Funding will be available to support signed agreements, consent orders, and FFCA mandates.

\subsection{Program Planning and Documentation}

This document provides a brief summary of each of the major elements of the program and discusses the respective objectives. It also sets forth the SF\&WMTDP strategy, identifies key program assumptions and their basis, and includes a process development plan; it is intended to serve as a basis to assure consistency and continuity throughout program planning activities.

The SF\&WMTDP plan is considered a "functional plan" under the Westinghouse Idaho Nuclear Company, Inc. (WINCO) Planning Hierarchy (see Figure 3). Input to strategic planning efforts, such as road-maps, the INEL Institutional Plan, and the INEL Strategic Plan, as well as the INEL ER\&WM Environmental Impact Statement (EIS), will be provided on an on-going basis. Changes to these documents that impact the SF\&WMTDP will also be incorporated as they occur. The SF\&WMTDP will be actively interfaced with other plant organizations, including Operations and Strategic Planning and Integration, in the development of technologies and processes in order to meet company needs.

Individual activities must be coordinated and integrated to assure all program efforts efficiently converge to meet program objectives. Success will require clearly defining, communicating, and maintaining focus on the program's end result while implementing strategies which meet interim needs, accommodate uncertainty in future conditions, and address all relevant success factors (i.e., organizational, environmental, institutional, legal, and other socio-economic issues). This planning will be performed as an integral part of the SF\&WMTDP and will be coordinated with other ICPP, INEL, and DOE strategic planning activities.

Throughout the SF\&WMTDP, various program documentation (i.e., planning, technical development, and implementation documents) will be developed and distributed to identify and present program criteria, plans, reports, etc. Figure 4 presents the hierarchy of ICPP SF\&WMTDP documentation. 


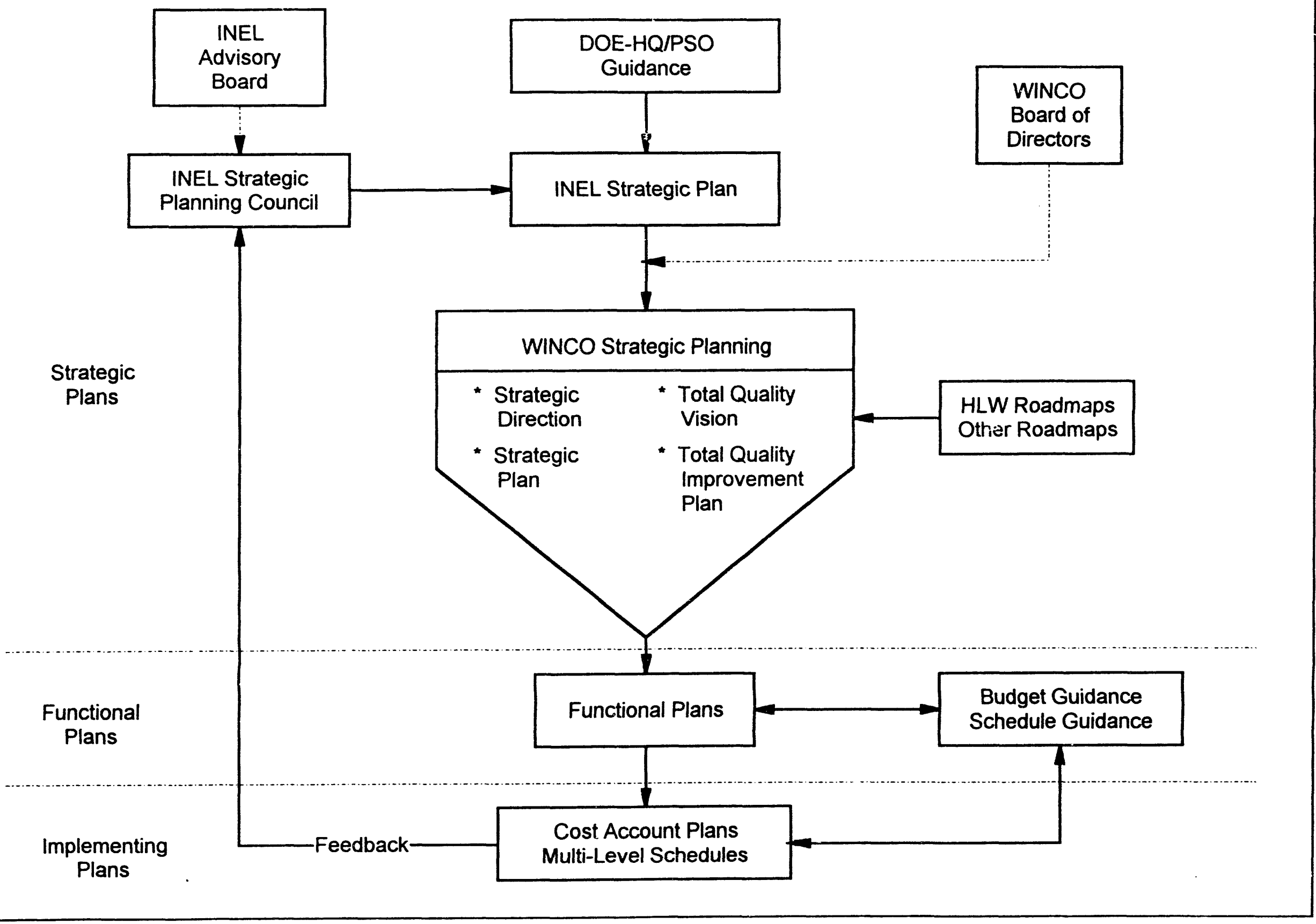

Figure 3: WINCO Planning Hierarchy 


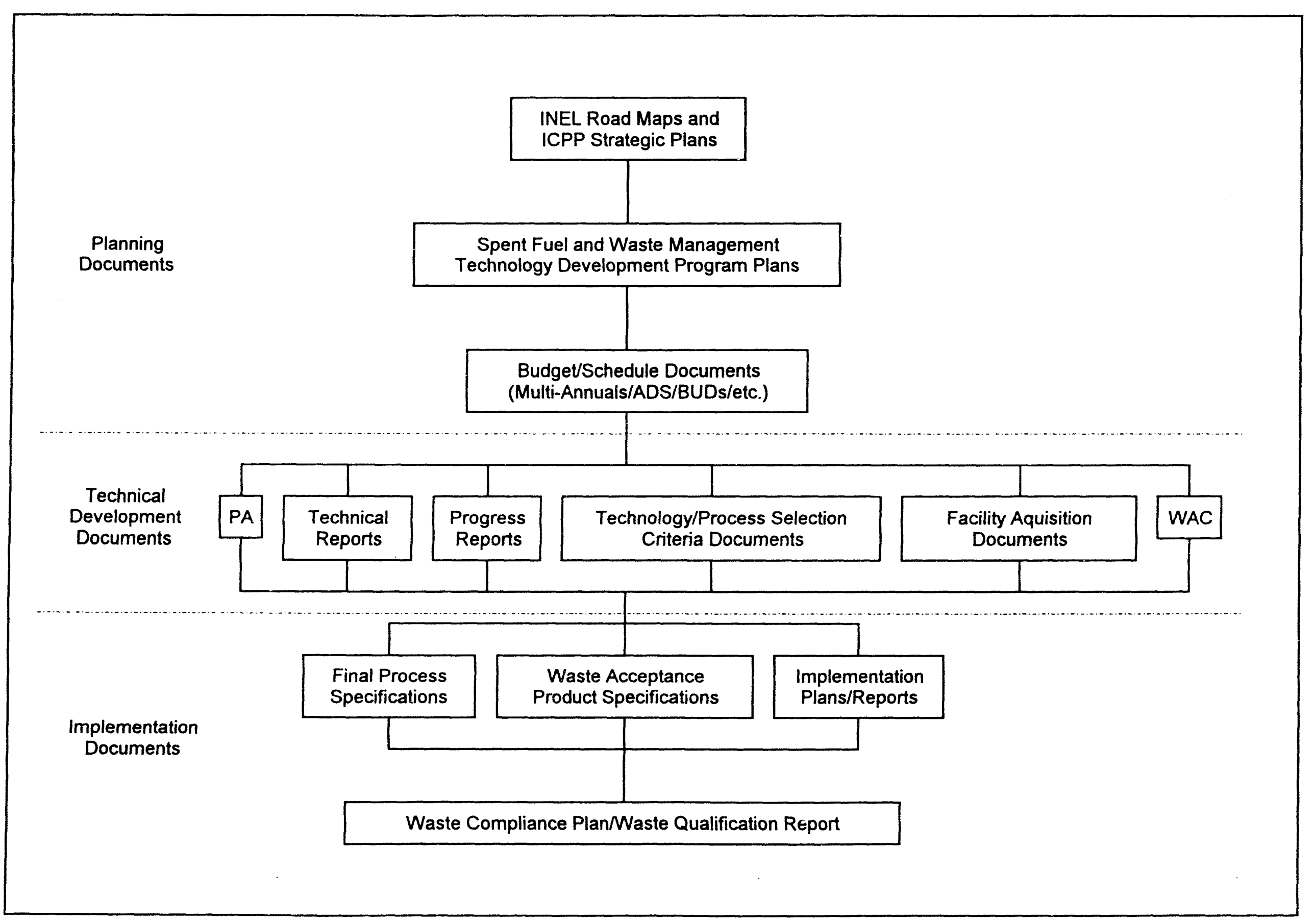

Figure 4: Hierarchy of ICPP SF\&WMTDP Documentation 


\section{PROGRAM ELEMENTS}

As stated, the primary focus of the Spent Fuel and Waste Management Technology Development Program (SF\&WMTDP) is to develop and demonstrate technologies that safely and efficiently deal with the spent nuclear fuel (SNF) and radioactive waste issues at the INEL. To help prioritize development efforts, program elements and activities have been divided into three broad categories: (1) Major Program Elements (Spent Nuclear Fuels Conditioning Process Development, Sodium-bearing Liquid Waste Conditioning Process Development, Calcine Conditioning Process Development, Interim Storage Technologies Development, and Product Specification), (2) Waste Minimization Program Elemeris (Metal Recycle, and Decontamination and Decommissioning), and (3) Supporting Program Elements (Systems Analysis, Stakeholder Interface, Technology Transfer, and Facilities Support).

\subsection{Major Program Elements}

\subsubsection{Spent Nuclear Fuels Conditioning Process Development}

Spent nuclear fuels (SNF) stored at the INEL are composed of a wide variety of cladding (aluminum alloy, stainless steel, graphite, and zircaloy) and fuel (uranium metal, uranium dioxide, uranium carbide, and uranium zirconium hydride) materials, with uranium enrichments varying in range from 3.5 to 93 atom percent. Also included in the INEL SNF inventory is a substantial quantity of spent commercial fuel, composed of zircaloy-clad uranium dioxide pellets. A number of the SNFs currently in storage, especially those that are aluminum-clad, are corroding, and existing underwater storage facilities no longer meet current storage regulations. Developing and implementing technologies to resolve these issues and to demonstrate new interim storage facilities is a top priority within the SF\&WMTDP. Technologies currently being considered to meet this need and prepare special fuels for final disposition are direct disposal (burial in a repository without prior conditioning), encapsulation (burial in a geological repository after encapsulating the SNF in a protective material), separation of uranium only, and separation of uranium and other actinides.

An SNF database is currently being developed to provide a comprehensive source of information and documentation regarding the inventory of SNF at the INEL. Where vital information is lacking, characterization is planned to provide the missing information. Three categories are planned to describe the levels of characterization. These categories are: (1) routine inspection of the spent fuel, (2) quantitative characterization to evaluate the need for fuel stabilization, and (3) material characterization to support the development of conditioning technologies. Each succeeding category will build on the information from the previous category. This information will better facilitate the development of processes for dry interim storage and the conditioning of SNF for final disposal. 


\subsubsection{Sodium-bearing Liquid Waste Conditioning Process Development}

Sodium-bearing radioactive wastes were produced from past decontamination and solvent recovery operations at the ICPP. The current method for disposing of sodium-bearing waste is to calcine it by blending it with first-cycle raffinate from SNF reprocessing to dilute the sodium concentration making it compatible with the New Waste Calcining Facility (NWCF) waste solidification process. However, with the recent decision to terminate SNF reprocessing at the ICPP, raffinate will no longer be available for blending with the sodiumbearing waste. Currently, the option of blending the sodium-bearing waste with nonradioactive aluminum nitrate (ANN) has been the only alternative available; however, the addition of significant quantities of non-radioactive ANN to a radioactive waste stream is unattractive due to increased radioactive waste volume and increased calcining, interim storage, solid waste immobilization, and long-term disposal needs and costs.

Under current RCRA Land Disposal Restrictions, all waste streams (including sodium waste) must be processed with BDAT prior to land disposal. In addition, a State of Idaho Consent Order to a Notice of Noncompliance from the EPA, regarding inadequate secondary containment of waste tanks, requires that the radioactive sodium-bearing waste be depleted from the tank farm pillar and panel tanks by 2009 and from the remainder of the tanks by 2015. To satisfy this order and the terms of the DOE/Navy/State of Idaho agreement as ordered in the September 20,1993, modifications to the U.S. District Court's Opinion and Order of June 28, 1993 (see Executive Summary), efforts will be made to:

- Qualify and verify a cost effective alternative method for processing sodiumbearing waste into a final low volume/low cost waste form; and

- Develop decontamination methods that are either compatible with current and future sodium-bearing waste processing methods, eliminate the use of sodium, or extract sodium constituents for recycle to be used for further decontamination and decommissioning (see section 2.2.2-Decontamination and Decommissioning).

Preliminary literature studies have identified direct solidification methods (calcination with additives, direct immobilization, and grouting) and sodium separation methods (neutralization, precipitation, solvent extraction, ion exchange, electrohydrolysis, and freeze crystallization) as possible treatment technologies for the sodium-bearing wastes.

\subsubsection{Calcine Conditioning Process Development}

Calcine currently being stored at the ICPP was produced from SNF processing raffinates and, according to current RCRA and NWPA definitions, is a mixed high-level waste. Future calcine produced from sodium waste need not be considered HLW, if stored separately from high-level calcine, and may be treated differently. To date, the ICPP has generated and is temporarily storing over $3,800 \mathrm{~m}^{3}$ of calcine in shielded stainless steel bins. Additions to 
this inventory are anticipated from the calcination of wastes currently stored in the tank farm and of those generated through decontamination of various ICPP facilities. Current calcine inventories include alumina, zirconia, stainless steel, zirconia-sodium blend, fluorinel, and fluorinel-sodium blend types.

According to the NWPA, HLW requires "permanent isolation" for disposal. As a hazardous waste, calcine is also subject to Land Disposal Restrictions (LDR), as mandated by the Hazardous and Solid Waste Amendments to RCRA. Therefore, for final disposal, the calcine at the ICPP must be processed into a form which immobilizes radioactive and hazardous elements readily leached from calcine upon contact with water. The SF\&WMTDP will develop and demonstrate a safe and cost-effective integrated process to immobilize the radioactive and hazardous constituents of ICPP calcine in a way that produces a waste form acceptable for final disposal. Technologies currently under consideration include dissolution (conversion to liquid by chemical reaction with acid), pyrochemical processing (a high temperature process to convert waste to a vapor or metallic liquid form), and separations (segregation of waste components using either mechanical or chemical processes).

\subsubsection{SNF Interim Storage}

Interim storage for SNF will be necessary until the final repository is available and the requisite treatment and transportation facilities are in place. The interim storage facilities must provide safe conditions for the SNF that eliminate unacceptable degradation through corrosion or other aging mechanisms. Additional interim storage capabilities are needed at the ICPP to safely store, inspect, and characterize existing and future SNF from which information needed to support future SNF conditioning processes can be obtained.

The primary technology used to date for storage of metal-clad DOE-owned SNF has been underwater storage pools that provide cooling, shielding, and corrosion control via water treatment systems. Limited dry storage facilities have been constructed and used for graphite fuels. The operating history of all DOE-owned SNF underwater storage facilities have shown conclusively that some SNF cannot be stored underwater for extended periods of time due to corrosion. The existing underwater SNF storage facilities and equipment also have degraded or do not meet new design requirements. Replacement storage facilities are necessary to resolve current storage facility problems and, assuming that the INEL ER\&WM EIS results in a Record of Decision (ROD), to accept for interim storage the projected production of SNF from DOE sponsored reactor programs. Dry storage is the preferred storage method based on commercial fuel storage experience and the interim storage time required before a permanent repository becomes available. In the near term, a dry fuel storage demonstration will be performed.

New technologies are necessary to support dry storage of the DOE-owned SNF. These technologies include development of the technical basis for corrosion control, elevated temperature impacts, safety and environmental risk assessments, monitoring and inspection intervals, etc. The technology development will include laboratory studies, engineering 
studies, technology demonstration using the available dry storage facilities (IFSF and CPP749), and provision to support construction of new storage facilities. Cooperative agreements with the commercial dry storage industry will be pursuer.

A feasibility study for a canning/characterization facility is being performed by the Projects Department. The technologies for characterization of SNF to support development of the ultimate disposal treatment process and the Waste Acceptance Criteria (WAC) will be developed. The technologies for establishing criteria for canning the SNF that has degraded in existing underwater storage facilities or that may need special storage medium, such as inert gas, will be developed to support the canning process.

Other technology development efforts expected to support interim SNF storage include: support of an accelerated effort for removing all SNF from the CPP-603 underwater storage facility by FY 2000; assessing the capabilities of the CPP-749 dry storage vaults and CPP666 underwater storage facility to meet extended interim storage requirements; and providing technology support for ongoing SNF interim storage operations and improvements.

\subsubsection{Product Specification Development}

Product Specification includes the development of Waste Acceptance Criteria (WAC), the completion of a Performance Assessment (PA) of waste forms at repository sites, and Waste Certification.

\subsubsection{Waste Acceptance Criteria}

A Preliminary Waste Acceptance Criteria (PWAC) will be completed to provide proper direction for the development program and a basis for future waste form evaluation. A WAC would normally be the responsibility of the repository operator; however, since a repository for all of the INEL SNF and wastes has not been determined and since technology development needs to progress, the SF\&WMTDP will develop a PWAC. The PWAC will define the waste form characteristics necessary to assure compliance with federal regulations. To confirm that the established criteria are sound and have a high probability of meeting federal regulations, Performance Assessment (PA) studies will be conducted by simulating waste form placement in various hypothetical repositories. These efforts are being conducted in close coordination with the DOE Office of Civilian Restoration and Waste Management (DOE-OCRWM), and will be subject to OCRWM peer reviews prior to official publication.

\subsubsection{Performance Assessment}

PAs will be conducted for the candidate waste forms, and reports will be issued illustrating the performance of the waste forms in hypothetical repositories. The waste form performance information will be used in the PWAC. Other information, 
such as major contributors to the radionuclide releases and parameters that have the greatest effects on the waste form's performance in the repository, will also be identified in the report. Such information will then be used to direct development efforts to ensure that the characteristics of the potential waste form are verified or confirmed.

The results of the PA will also be used in the System Models to rank process options based on established criteria. The information will be used to guide the developmental efforts and to select SNF and radioactive waste conditioning and disposal processes with the highest probability for success.

One aspect of the PA, which applies to the safe emplacement of SNF, is the consideration of scenarios under which the SNF might form a critical mass. The regulatory requirements for long-term storage is not clear at this time, but it is expected that criticality must be prevented for at least 10,000 years, however it is speculated that criticality prevention requirements will evolve to the point that a criticality incident must not occur over any period of time. This could pose problems for direct disposal and encapsulation technologies associated with SNF, since fissile material migration and deposition cannot be ruled out over geological time scales. The SF\&WMTDP will address the criticality safety issues associated with placement of highly enriched SNF in a geological repository.

\subsubsection{Waste Certification}

The criteria to be met for the disposal of SNF and radioactive waste are based on EPA and NRC regulations that were established to supplement RCRA, the Atomic Energy Act (AEA), and the NWPA. A Waste Acceptance-System Requirements Document (WA-SRD) outlining top-level criteria required to certify DOE-owned radioactive wastes for disposal is under development. The WA-SRD will describes the operational requirements that must be met for DOE to accept title to waste and assigns responsibility for various aspects of the operation. Once a repository is selected, the repository operator will be responsible for issuing specific WAC for the repository. Waste form producers will be responsible for certifying that their waste forms meet established criteria.

The first step in certifying a waste form is to generate Waste Acceptance Product Specifications (WAPS) based upon the repository's WAC. The WAPS will describe in detail the physical and chemical properties and other characteristics that the waste form must exhibit to meet the WAC. The methods to be used to demonstrate compliance with the WAPS will be described in a waste form compliance plan and will include: laboratory tests, analysis of process control data, and prototypical production runs. 
Presently, approved WAPS and WAC's are unavailable; it is, therefore, difficult to develop and assess candidate waste form fabrication technologies. However, there is enough generic information available about potential disposal sites to allow hypothetical or preliminary WAC (PWAC) to be formulated. This PWAC, and the preliminary WAPS derived from them, will form a framework to be used to guide development and selection of candidate waste form fabrication technologies. As the waste form development process proceeds, preliminary specifications will be revised to take advantage of technological advances. A preliminary waste compliance plan will be prepared to form a basis for selecting conditioning processes, quality assurance specifications, and analytical methods that will eventually be used to qualify the waste form. The waste qualification report will document the actions taken to qualify the waste forms.

Preparing preliminary criteria, specifications, and qualification plans will expedite the licensing process and provide guidance for development activities leading to a process plan for a waste processing facility.

\subsection{Waste Minimization Program Elements}

\subsubsection{Metal Recycle}

A program to address the dispositioning of radioactive scrap metals (RSM) throughout the DOE complex was developed by WINCO and currently plays a substantial role in meeting the ICPP's SF\&WMTDP objective of waste minimization. Metal Recycle objectives are: (1) to provide lead support to EM-30, who is responsible for DOE RSM, (2) to assess stainless steel melting and fabrication technologies, (3) to recycle ICPP contaminated stainless steel, and (4) to facilitate privatizing recycling of radioactively contaminated metals on a national basis.

The WINCO Metal Recycle program addresses both INEL needs and DOE national needs. The local needs include disposition of stainless steel generated during reracking of the ICPP Fluorinel Dissolution Process and Fuel Storage (Cr P-666) fuel storage basin, carbon steel from upgrade of the dry fuel storage facility, and future decommissioning of INEL facilities. An inventory at the INEL will be completed to determine the current supply of radioactive scrap metal. Inventories of radioactively contaminated metals at other DOE sites will also be completed to support the national aspect of the Metal Recycle Program.

In order to effectively evaluate the feasibility of recycling DOE radioactive scrap metal, a thorough cost analysis must be performed. This is the driver for much of the national portion of the program. The cost analysis will encompass metal supply, demand for recycled products (such as shielding or canisters for radioactive wastes), facility operation, avoided disposal costs, stakeholder input, and regulatory requirements. A systems approach is being employed to ensure all relevant factors are considered. 
The technology for stainless steel melting which is necessary to accomplish recycling of radioactive scrap stainless steel does not currently exist within private or government facilities. WINCO and private industry will develop these technologies through cooperative agreements and other privatization initiatives.

\subsubsection{Decontamination and Decommissioning}

Past decontamination and solvent recovery activities at the ICPP have resulted in the accumulation of 1.5 million gallons of radioactively-contaminated sodium-bearing liquid waste. Future activities, using the current decontamination techniques of chemical/water flushes and steam-jet cleaning, could result in the production of 5 million or more additional gallons of waste. New decontamination methods which result in higher decontamination factors and generate lower amounts of sodium-bearing and other liquid wastes are needed.

The primary initiative of the WINCO decontamination program is the development of methods to eliminate or minimize the use of sodium-bearing decontamination chemicals. Three decontamination methods were chosen for evaluation (cold-scoping studies) based on their applicability to problems at the ICPP. They include: abrasive grit blasting, $\mathrm{CO}_{2}$ pellet blasting, and light ablation. Decontamination testing of these three techniques will be performed on existing ICPP contamination (hot testing), and integrated into plant processes where applicable. Additional candidate methods include: the DECOHA regenerative fluoboric acid method, cerium nitrate oxidation, electro-polishirg, and the destroying of organic acid and/or complexant systems by reducing them to water and carbon dioxide. Technology transfer opportunities to the private sector will be employed where practical to reduce costs and assist the commercial market in this ever-growing area.

\subsection{Supporting Program Elements}

\subsubsection{Systems Analysis}

A major challenge for both managers and organizations striving to deal with complex and changing programs is the ability to understand and manage the impact of individual decisions and actions on an overall programmatic basis. To help understand and manage problems, complexities, uncertainties, and to help make better programmatic decisions associated with the SF\&WMTDP, the Systems Analysis (SA) organization is applying industry accepted methods to enhance understanding and to identify key factors for success. Additionally, implementation of SA techniques will enable program personnel to (1) test the near- and long-term consequences of various strategies and scenarios, (2) establish the basis for informed decision making, (3) assure that optimum strategies are developed and pursued, and (4) enhance defensibility and credibility of program decisions. 


\subsubsection{Systems Integration}

Key factors in the success of a systems approach are effective inter-program communications and the maintenance of a program-wide perspective when making decisions. The Systems Integration function acts as a catalyst for inter-program communication and facilitates group interaction using organizational learning techniques to help clarify objectives, scrutinize implicit assumptions, surface inconsistencies, and build shared understanding of ritical issues. Additionally, Systems Integration helps identify and resolve cross-cutting issues that need high-level attention and ensure that management strategies consider all factors which affect program success, such as stakeholder concerns, regulatory uncertainties, legal matters, institutional issues, budget requirements, and sociological concerns. Systems Integration also assures proper application of systems methods to support program needs. Testing of management strategies and their underlying assumptions, using a systems perspective, will minimize tunnel vision and help avoid extraneous activities.

\subsubsection{Systems Modeling}

Systems computer models are computer simulation programs developed using computer software and hardware that allow "what if. . ." testing of the various decisions, strategies, and approaches for future scenarios. Systems Modeling will be used to evaluate program strategies based on both technical and non-technical factors, such as regulatory compliance, risk, cost, public perception, and stakeholder interest, and to simulate the effect of future uncertainties. Systems Modeling assists the decision-making process by evaluating future possibilities based on the relationships among the various factors affecting the results of the program. As the development program advances, these models will help evaluate various changes and alternatives in issues. In this way, Systems Modeling will continue to help focus the development efforts on the piocesses that have the highest probability of success.

\subsubsection{Performance Assessment}

The selection of candidate processes will be supported by a Performance Assessment (PA), an internationally accepted method required by the Code of Federal Regulations (CFR) to analyze engineered disposal systems for proper isolation of radioactive waste. PAs quantify aspects of waste disposal decisions by identifying and examining the effects of various processes and events on the performance of the disposal system and estimating the cumulative releases of radionuclides and hazardous materials as required by regulatory agencies.

\subsubsection{Stakeholder Interface}

Stakeholder (i.e., anyone or any group with interest in the program-public, State, special interest groups, etc.) acceptance is a major factor in determining the success or failure of the 
SF\&WMTDP objectives. DOE's Office of Policy and Program Information (EM-4) has established a public participation policy that focuses on increasing the role of stakeholders in DOE's decision-making processes. The goal of increased stakeholder participation in the SF\&WMTDP activities at the INEL is to create an open, visible, and fair process that results in decisions that attend to the technical, socioeconomic, legal, institutional, environmental, and health and safety concerns of the stakeholders and DOE. Achieving this goal requires that stakeholder questions, concerns, and needs be identified early and that efforts be made to seek input and integrate stakeholder concerns into the decision-making process. To accomplish this goal the INEL has developed the Public Participation Plan to achieve the following:

- Establish and maintain two-way communication with stakeholders through workshops, working groups, and person-to-person contacts;

- Present understandable, consistent, factual information to the stakeholders in a timely manner;

- $\quad$ Provide consistent information throughout the SF\&WMTDP;

- $\quad$ Address stakeholder issues and focus efforts on resolving conflict; and

- Be re!ponsive in explaining how public input was or was not used in INEL decision-making.

The SF\&WMTDP will support INEL Public Participation Plan initiatives and will coordinate specific stakeholder programs through the INEL Public Participation Plan office.

\subsubsection{Technology Transfer}

Respondir, to DOE's emphasis to share developed technologies, knowledge, and information with the private sector, the INEL has developed a Technology Transíer Program. Through Technology Transfer, the SF\&WMTDP will strive to develop a stronger partnership between the INEL and private industry. Implementation of the Technology Transfer Program began in January of 1993, and the first of a series of workshops designed to expose WINCO employees to the technical, intellectual, and legal ramifications involved in the Technology Transfer process was provided in August, 1993. Information presented at this and other ongoing workshops will be applied directly to the ICPP SF\&WMTDP in effort to apply SNF and radioactive waste management technologies to problems beyond the boundaries of the INEL.

\subsubsection{Facilities Support}

Facilities are required for developing and implementing technologies associated with the SF\&WMTDP objectives. Required testing facilities may include: (1) laboratory space to 
identify and evaluate candidate technologies, (2) cold pilot-plant space to perform detailed evaluation of candidate processes, and (3) Hot pilot-plant space for integrated testing of selected processes. New facilities, in addition to existing facilities, are necessary for both cold and hot pilot-plant testing. A production facility is required for process implementation and consist of a separation, LLW denitration and grouting, HLW vitrification, offgas/ventilation, LLW drum storage, and bulk chemical storage facilities. The design of the production facility incorporates processing of sodium-bearing and calcine waste with a possibility to expand into processing of SNF.

\section{PROCESS DEVELOPMENT PLAN}

The Process Development Plan of the SF\&WMTDP, shown in Figure 2, consists of three periods of technology development (i.e., Identify Candidate Technologies and Processes, Perform Detailed Evaluation of Candidate Technologies, Integrated Testing of Candidate Technologies), each leading, respectively, to a key decision point (i.e., Select Candidate Processes for Evaluation, Select Processes for Integrated Testing, Select Final Process) with process implementation following the final selection. The fundamental philosophy of the plan is the systematic narrowing of a large number of candidate process options through identification and evaluation, laboratory and component-scale testing, pilot plant-scale testing, and hot plant testing of SNF and radioactive waste disposal process options. Optimally, one safe and economical conditioning process will be implemented.

In selecting processes for further evaluation and testing, candidate options will be evaluated against the following criteria:

- Safety of process to workers, the public, and the environment;

- Development, implementation, operation, and total program costs;

- Acceptability of the process to stakeholders;

- Volume ratios of LLW and HLW produced;

- Number of final waste forms;

- Flexibility of the process to handle multiple input streams;

- Technical maturity, including required development time, of the technologies being considered within the respective processes;

- Criticality, technical, and contamination risks;

- Compatibility with other DOE-owned SNF and radioactive waste; and 
- Compliance with all applicable regulations.

- Overall cost of process, facilities and operation.

The evaluation process will consider process development technical data and test results, as well as employ systems analysis tools to help further understand the consequences of various strategies for potential future scenarios. The result of each decision point will be the selection of the most promising process options to continue on through the development process. Ultimately, the process option that best meets the stated criteria will be selected for development into an operating facility(s) to condition and prepare INEL SNF and radioactive waste for placement in a final repository.

\subsection{Identify Candidate Technologies and Processes}

The SF\&WMTDP is currently developing and evaluating process flowsheets to identify technical feasibility and compatibility of candidate technologies with diverse input streams; preparing Preliminary Waste Acceptance Criteria (PWAC); developing and implementing Systems Analysis tools (i.e., Systems Integration, Systems Modeling, Performance Assessment) to support informed decision-making; and establishing testing needs and permitting requirements. Waste Acceptance Criteria and Performance Assessments will be used throughout the development process to evaluate the waste forms of the proposed processes to ensure the selected process flowsheet yields a product suitable for final disposition. These efforts will provide the information necessary to narrow numerous SNF and radioactive waste processing options to a much smaller field for continued development and evaluation.

Candidate technologies will be identified according to their utility in the overall SNF and radioactive waste conditioning and dispositioning process. Preliminary evaluations will be conducted for each technology to define the operating envelope for the specific unit operation, to quantify unit operation efficiency, to assess scaling effects, reliability and maintainability, and to characterize the output of the unit operation. Data from these evaluations will be used to compare competing technologies and select candidate process for evaluation on a cost vs. benefit basis, and to define specific requirements for each phase of process development.

\subsubsection{Process Flowsheet Development}

Process flowsheets are being developed for each disposal process option to analyze SNF and radioactive waste streams through various processing operations. These diagrams illustrate, in addition to overall processing procedures, quantitative input/output volume ratios for each waste stream and the compatibility of each option for various SNF and radioactive waste types. Budget and scheduling requirements, health and safety considerations, and public acceptance levels will be estimated in a generalized list of assumptions and in data deficiency 
reports that will accompany each flowsheet. Data will be used in conjunction with established criteria to determine the technical feasibility of each alternative from a thermodynamic and engineering standpoint.

\subsubsection{Decision Support Tool}

Identification of candidate technologies and processes involves a preliminary evaluation of both technical performance and the ability of each potential candidate process to withstand changes in various intangible issues related to its selection. A Decision Support Tool (DST), a computerized system model, will aid in the identification and preliminary evaluation of candidate technologies by simulating the effects of such things as risk, cost, and public acceptance of a given process option.

The DST is being developed with the assistance of personnel throughout the SF\&WMTDP to adequately consider numerous perspectives on issues crucial to the selection process. As the selection of candidate processes narrows, the DST will be refined to meet the precise needs of the program and to provide more sophisticated technical evaluations of the candidate processes at each phase of the ICPP SF\&WMTDP.

\subsubsection{Process Options}

As illustrated in Figure 5, there exist basically three general disposal process options, direct disposal (direct placement of the SNF/radioactive waste, with no additional conditioning, into a canister for disposal), conditioning (grinding, chopping, or otherwise conditioning $\mathrm{SNF} /$ radioactive wasie, then encapsulating it into a protective material prior to emplacement in a disposal canister), and separations (separation of uranium and possibly other actinides utilizing either pyrochemical or aqueous technologies).

\subsubsection{Direct Disposal Technologies}

There are, at present, three technologies being considered for the direct disposal of SNF and radioactive waste. Options A and C (see Figure 6) entail the separate emplacement of radioactive waste and SNF, respectively, into canisters for disposal. Option B, on the other hand, proposes to package both waste types into the same canister to maximize usage of the available canister space, and will involve the initial packaging of each waste type prior to emplacement within the canister (SNF can either be packaged as whole pieces or shredded prior to packaging). To facilitate development of the Direct Disposal option, efforts are underway to identify and qualify materials required for the construction of a multi-purpose canister (MPC) and an engineered barrier system (EBS) 


\subsection{Multi-purpose Canister Development}

At an October 1992 meeting with DOE-HQ, -EM and -OCRWM, INEL was asked to lead a repository waste form barrier/canister development team with the responsibility of establishing guidelines for the consideration of a 10,000 year canister in conjunction with the DOE SNF/radioactive waste technology development program. The status of DOE SNF and radioactive waste and development of long-lived barrier/canisters will be reviewed through team meetings. Form these meetings an initial plan will be formulated for evaluating the barrier/canister option relative to other disposal alternatives. Other package components, such as the multi-purpose canister (MPC) study and engineered barrier system (EBS) development, will be leveraged through ongoing technical reviews and future team meetings.

The MPC development program, in conjunction with commercial SNF transportation, storage, and disposal, was started in February, 1993 by TRW, the prime Management \& Operating contractor to DOE-RW. TRW plans to examine nuclear criticality as one of the pirameters and anticipates the completion of a MPC Waste Package Design Considerations Report by October, 1993. Additionally, Babcock \&Wilcox is developing an advanced conceptual design of a waste package. Seven waste package designs, including some for long-term (10,000 years) performance, are being evaluated by $\mathrm{B} \& \mathrm{~W}$.

Limited testing, in the US to date has been completed to determine the effects of differing repository media on the various materials being considered for long-lived canisters. Preliminary assessments of repository effects may only be possible under assumed repository conditions, however the team feels it may be able to use test results for other repository media from Canada, Sweden, Germany, and Switzerland as potentially applicable to a second US repository. It is the goal of the team to provide specific recommendations concerning parameters and/or assumptions to be considered in constructing a range of direct-disposal options. A waste form canister and a plan for evaluation of the direct-disposal options will be proposed, from these efforts, as early as possible.

\subsubsection{Conditioning/Waste Stabilization Technologies}

The ICPP SF\&WMTDP approach to conditioning/waste stabilization technology evaluation and down-selection can be illustrated using one of the candidate waste stabilization technologies already identified. Calcine can be converted into a stabilized waste form consisting of various oxide ceramic phases bonded together by an amorphous (glass) phase. This stabilized waste form, called a glass-ceramic, is formed by reacting calcine with non-radioactive chemical additives in a process known as hot isostatic pressing (HIP). In order to evaluate HIP technology for 
stabilizing ICPP calcine, statistically designed experiments will be performed to map pertinent characteristics of the product (waste form) onto the process's operating parameter space. The same experiments will also provide data on the stability of the process (indicative of product reject ratio) and throughput rate. Experience gained during HIP operation will be used to estimate process down time and maintenance requirements. Additional experiments will assess requirements for HIP operation in remote environments, and scaling effects on HIP canister deformation.

A similar approach will be followed for all SNF and radioactive waste conditioning/stabilization process options. Initially, experiments will be performed using simulated (non-radioactive) material, but a final series of experiments using actual radioactive material will be necessary to complete the data set. These data can then be used to compare processes to other candidate conditioning/stabilization technologies.

\subsubsection{Separations Technologies}

Separations te:hniques are used to partition (segregate) portions of various waste streams which in turns allows for recycle of valuable products and high-level waste volume reduction. Previously, separations was only used to recapture the enriched uranium from irradiated fuel. Because disposition of the high-level waste is expected to be costly, waste volume reduction is a new focus point for the separations technology development. Technologies under consideration are being paired according to their ability to handle multiple feed streams, through the combination of various process flowsheets.

Separations technology development will be performed using data from previous separations activities performed to recover enriched uranium. DOE-owned SNF, Navy fuels, and some commercial Light Water Reactor (LWR) and Boiling Water Reactor (BWR) reactor fuels will be considered for evaluation. These evaluations will be designed to identify the strengths and weaknesses of each process option for testing that will occur after the first decision point. 


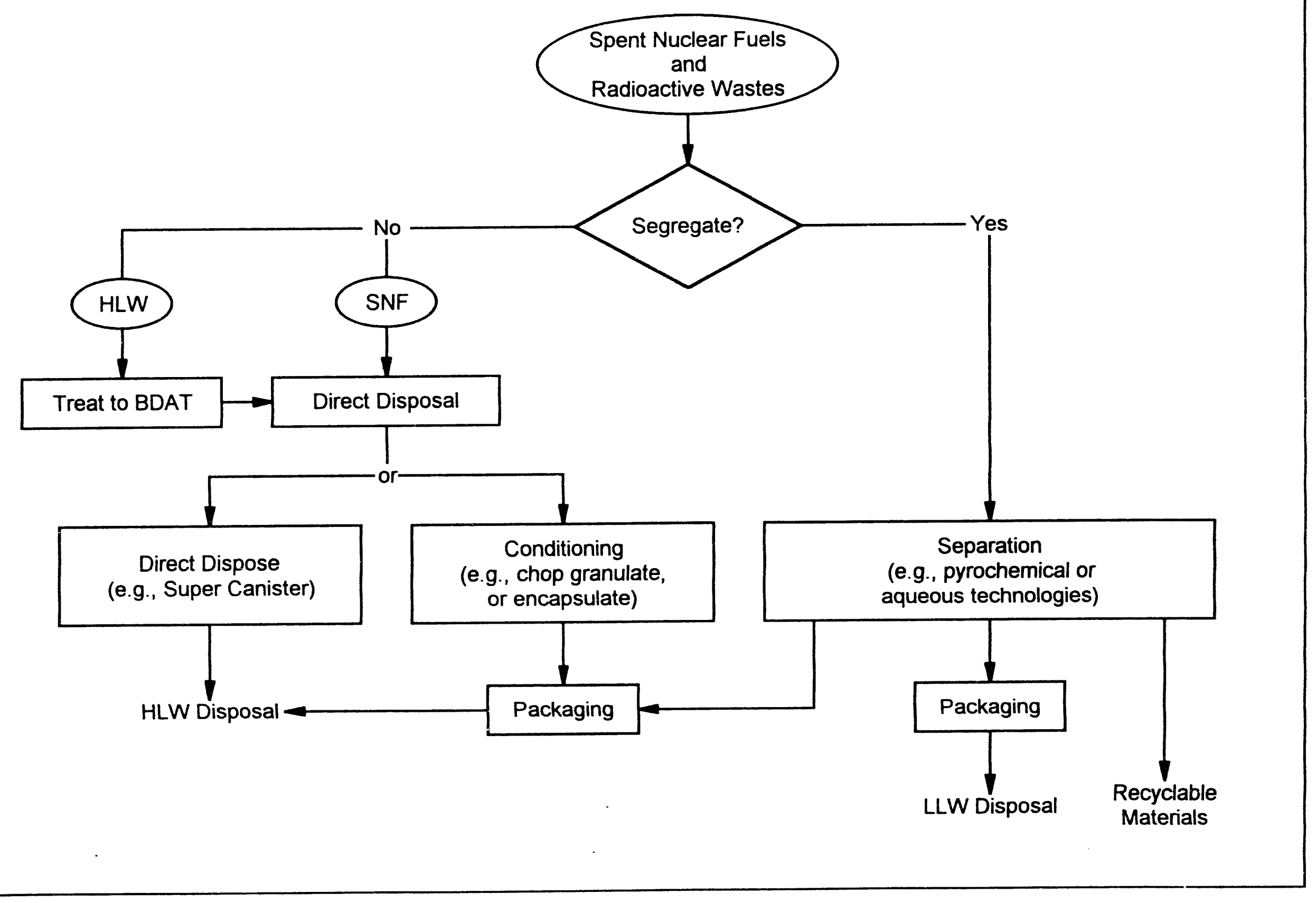

Figure 5: Process Disposal Options 
Within each of the three general disposal process options, there are four potential process steps or phases, namely: (1) Headend/Pretreatment, (2) Separations, (3) Stabilization or Packaging, and (4) Final Disposition. Several technologies are currently being pursued by the development program for each of these four process steps. Technologies developed for each of the process steps will be integrated to develop a process that will accept all INEL input streams and condition the SNF/radioactive waste for final disposal.

Technologies currently under consideration include:

\section{Headend/Pretreatment}

- Retrieval: Ability to remove waste from storage locations.

- Burning/Voloxidation: Process of oxidation used to separate components of SNF.

- Mechanical Disassembly: Reducing the size of the SNF assembly by cutting or grinding with potential of segregating non-fuel portions.

- Shredding: Reducing the SNF assembly to small chunks using a mechanical shredding machine.

- Calcination: Conversion of a liquid waste to a granular solid form by thermal decomposition of acid solution.

- Oxidation/Reduction: Conversion of elemental valence which can be used for preferential separation methods such as precipitation, extraction, etc.

- Dissolution: Conversion of solid SNF or waste to a liquid by chemical reaction with acid.

- Halide Volatility: Converting an element to a halide gas that can be preferentially separated by trapping the gas at different temperatures.

\section{Separations}

Solvent Extraction: Process using counter-current aqueous and organic streams and changes in chemical conditions to selectively force one component into the organic phase and then to recover that component in an aqueous phase.

- Freeze Crystallization: Process that uses the ability of ice crystals to reject salt to separate a solution into a salt rich and a salt depleted stream (useful for sodium ion reduction).

- Ion Exchange: Process which allows ions in solution to preferentially attach to the surface on an organic resin or inorganic clay in exchange for other ions pre-deposited on these surfaces.

- Supported Liquid Membranes: Membrane filter used to extract target elements from an aqueous solution.

- Volatilization/Distillation:Process using the differential ability of certain components to enter a vapor phase upon heating.

- Pyrochemical/ Pyrometallurgical: High temperature processes which converts a waste form to a vapor or metallic liquid form. 
- Precipitation; Process which uses the properties of certain components to be included in a solid phase formed from a solution upon cooling or chemical addition.

- Fractional Condensation: Process which uses the differential ability of certain components to leave a gas phase and form solid or liquid phases as temperature is reduced.

- Electrolysis: Process which separates components using a chemical transformation driven by electrical current or voltage.

- Off-Gas Treatment: Filtration or chemical process to remove hazardous/radioactive contaminants from the process off-gas.

\section{Stabilization/Packaging}

Glass: Incorporation of waste into a matrix of non-crystalline, super-cooled liquid.

- Cementation/Grouting: Incorporation of waste into a matrix of solidified hydrated oxides.

- Glass-Ceramic: Incorporation of waste into a form which contains some glass, but which also contains a large portion of crystalline matrix.

- $\quad$ Non-Radioactive ANN Addition: Preparing a high sodium solution for calcination by addition of aluminum nitrate in order to avoid calcine agglomeration.

- Canning: Sealing waste inside a metal container.

\section{Final Disposition}

- Shallow Land Burial: Disposal of waste in a near surface pit.

- $\quad$ Monitored Retrievable Storage: Placing waste in an engineered facility which is designed for easy inspection and removal of the waste containers.

- $\quad$ Mined Geological Disposal Site: A burial facility located in a stable underground rock formation.

- Greater Confinement Disposal: Disposal of waste in a deep shaft repository.

- $\quad$ Recycle: Reuse of decontaminated materials for the construction of waste canisters, facility development, etc., and reuse of usable byproducts extracted from conditioning processes.

Figures 6 through 9 show sample schematics for each general process option being considered for conditioning and disposing of SNF, sodium-bearing liquid waste, and calcine. 


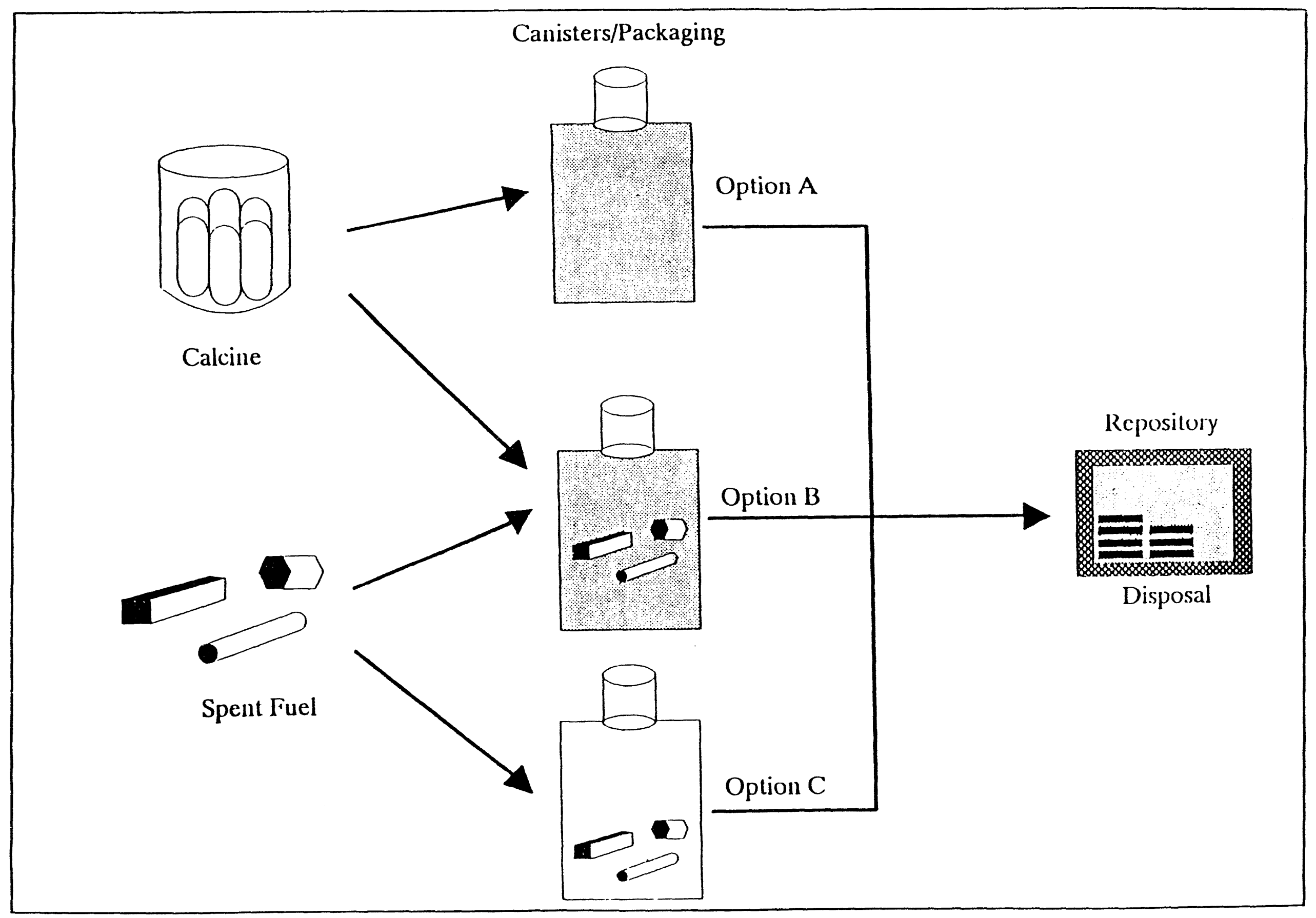

Figure 6: Process Flowsheet for Direct Disposal Process Option 


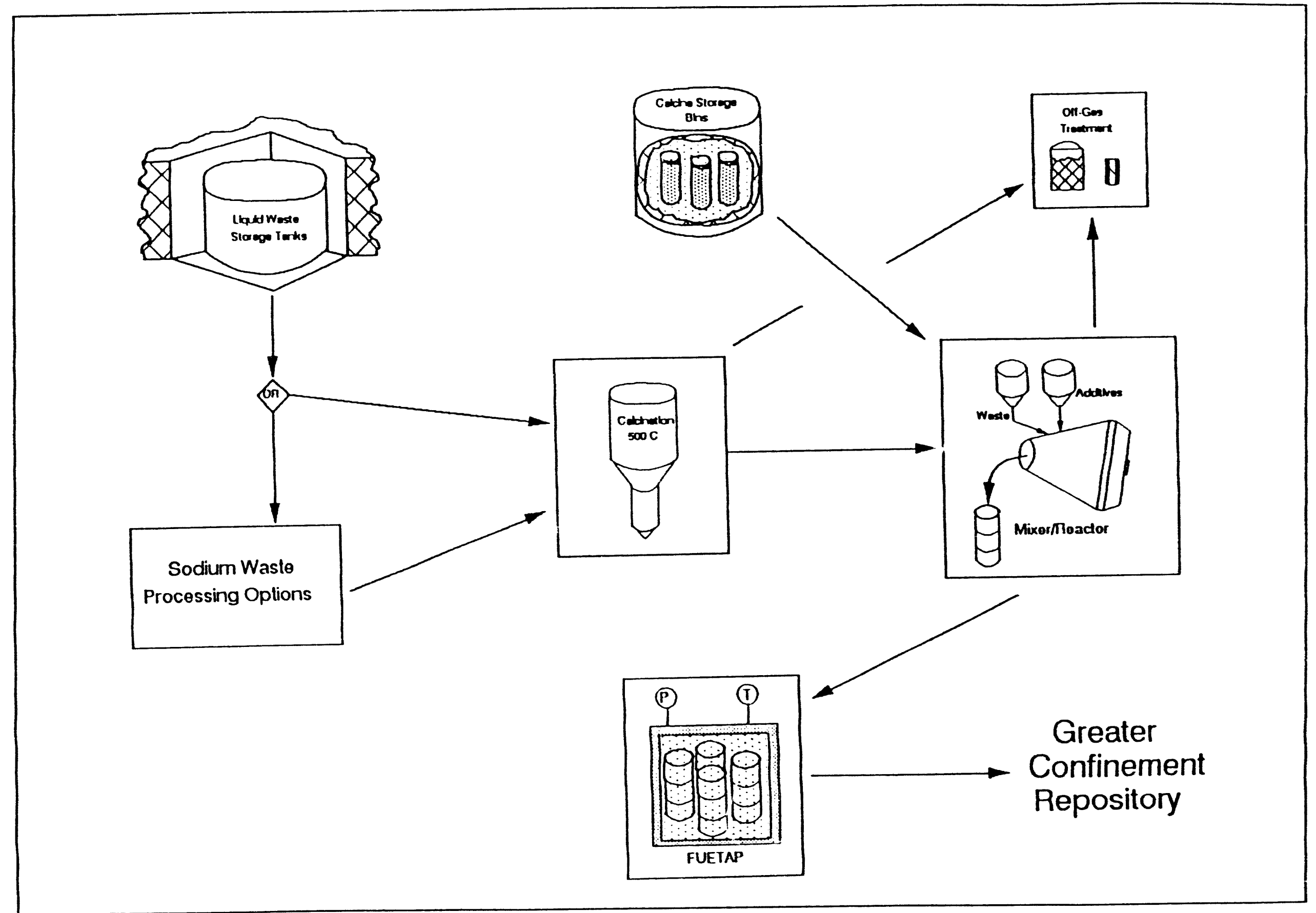

Figure 7: Process Flowsheet for Conditioning Process Option 


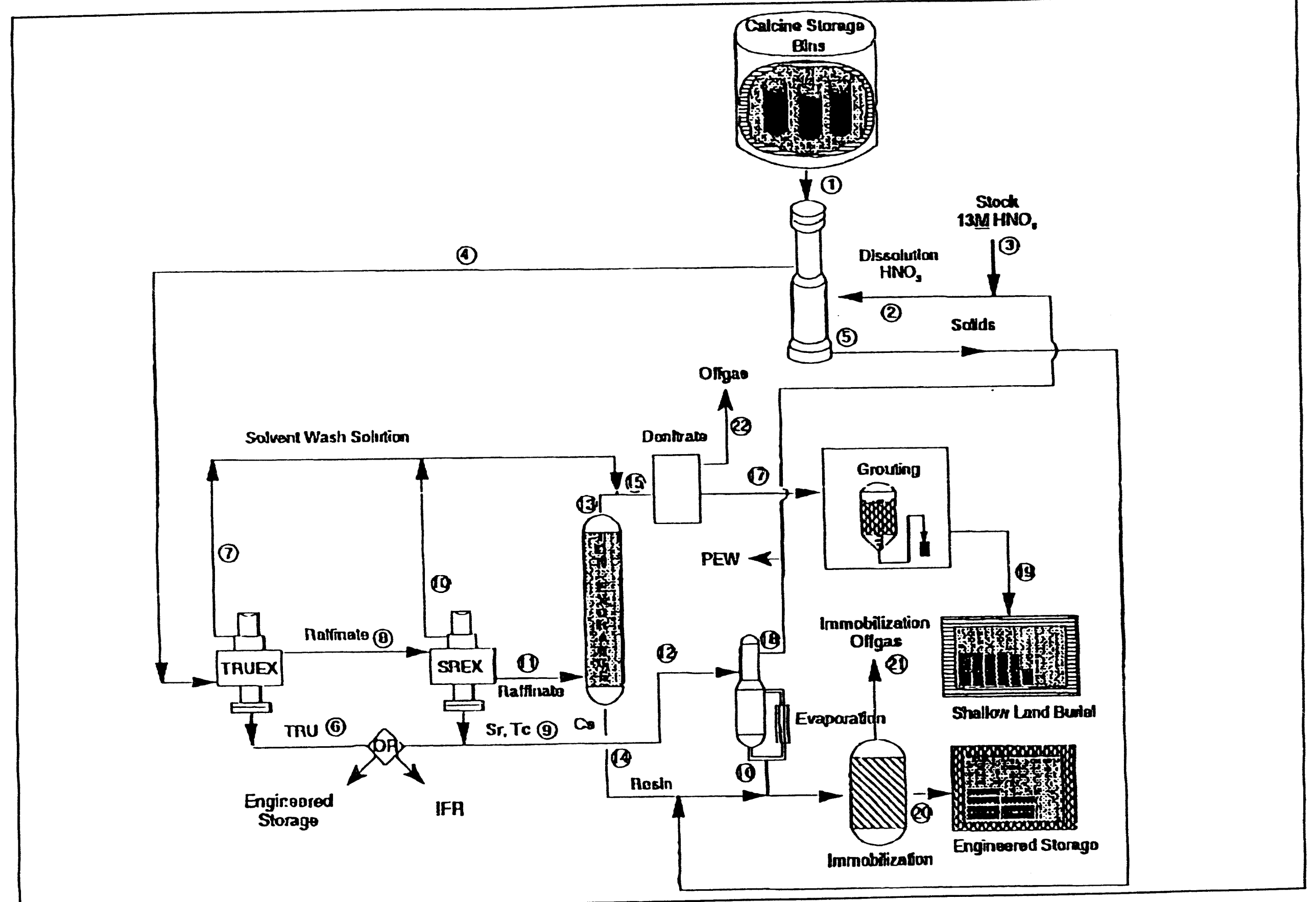

Figure 8: Process Flowsheet for Aqueous Separations Process Option 


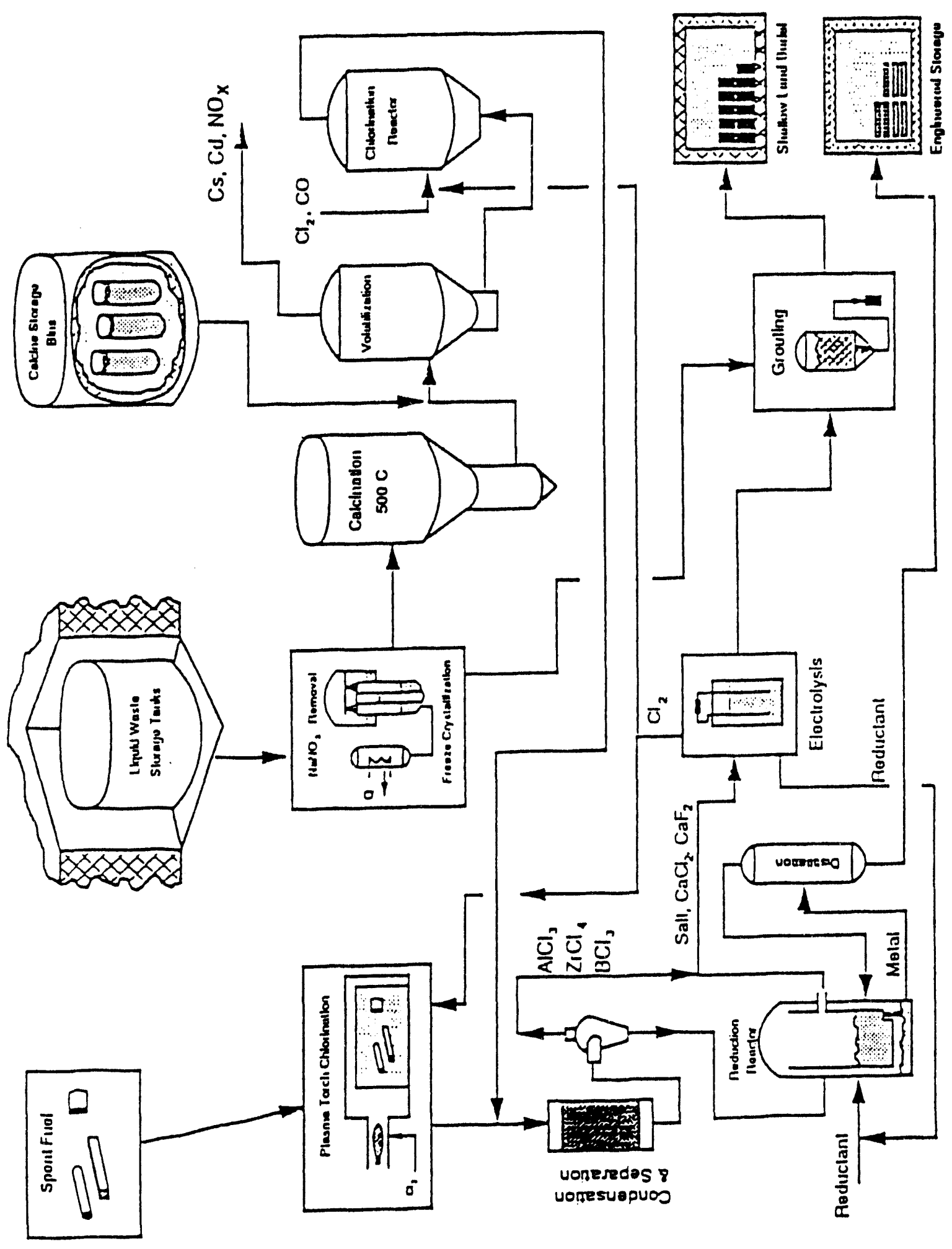

है 


\subsection{Select Candidate Processes for Evaluation}

A technical review team composed of program personnel will evaluate data obtained through process flowshect development and DST analyses. This information will be used to establish the compatibility of each process option to the needs of DOE, INEL, and other interested parties. Based on the review teams evaluation, plans will be developed and technical recommendations made concerning which process options should proceed to the detailed evaluation (i.e., laboratory-scale testing) phase of the program. Recommendations and plans will then be discussed with stakeholders for input, and candidate processes will be selected for further evaluation based on the ability to meet the stated needs.

\subsubsection{Development Plans for Technologies}

Developing processing and disposal technologies and processes for SNF and radioactive waste will involve a systematic experimental program. The approach will include laboratoryscale and pilot plant-scale testing of new technologies and the verification of the application of existing technologies to the unique INEL SNF and radioactive waste. In most cases, testing with samples of actual SNF and radioactive waste material will be required to demonstrate the technology and verify process flowsheet assumptions.

\subsection{Perform Detailed Evaluation of Candidate Processes}

Laboratory-scale testing will be performed on candidate technologies to provide sufficient data to confirm process flowsheets and define pilot plant-scale testing needs. Data acquired from such tests will include life-cycle cost analyses, processes scalability assessments, and waste generation studies for each candidate process. Additionally, environmental and National Environmental Policy Act (NEPA) permitting activities will be pursued and facilities will be made available to further support the technology development schedule (see section 4 - Facilities Support).

\subsection{Select Processes for Integrated Testing}

Based on laboratory-scale test results, as well as the criteria stated above, program management will use Systems Analysis tools to evaluate the cost, waste volume, and scalability for each process option to further narrow the field of viable candidate processes. Compatibility with current regulatory requirements and with environmental, safety, and health concerns will be a primary consideration of this decision-making process.

Considerable effort to maintain communications with DOE and stakeholders during the selection process will ensure that the concerns of the DOE and stakeholders are addressed. 
The process(es) chosen for additional testing will be included in the Federal Facilities C mpliance Agreement (FFCA) agreements with the State of Idaho.

\subsection{Integrated Testing of Selected Processes}

Pilot plant-scale tests will be performed on each remaining process to confirm and expand flowsheet data, and to resolve scalability issues. Compatibility with diverse input streams will be studied, and functional and operational requirements will be established. Emphasis will be primarily on completing systems studies on integrated concepts and on getting facilities on-line to support and perform integrated pilot plant-scale testing. Additionally, efforts will be made to resolve final product interim storage and disposition issues until a repository is available.

\subsection{Select Final Process}

A final process will be selected based on test results from previous program phases. Investigations and reports on the scalability, design flowrates, sizing, and operating conditions for each unit operation will be reported to support the project.

As in previous selection steps, the criteria specified above and stakeholder input will be used to select the final process. Stakeholder acceptance will be reviewed by the INEL/DOE-ID stakeholder Advisory Committee. Issues brought from the Advisory Committee will be worked during this evaluation period until both parties acknowledge the resolution.

\subsection{Process Implementation and Operational Facilities}

As technologies are developed and the final process(es) is selected and implemented, facilities will be required for the preparation of SNF and radioactive waste for final disposition. These facilities will be housed in a full-scale production complex consisting of both new and existing facilities, such as the Flourinel Dissolution Process (FDP) facility and the Fuel Processing Restoration (FPR) facility. Feasibility studies for this production complex are underway, with conceptual design efforts expected to begin in FY '94. This complex will be designed to accept either the highest priority program or several programs simultaneously.

\subsection{Waste Form Shipment}

Transportation is a key element of the waste disposal system and may prove to be an important element of waste form production. Most waste forms will require some interim storage between production and shipment. If interim storage cannot be provided as an 
integral part of the production facility, it may be necessary to transport waste forms from the production facility to another interim storage facility.

Transportation requirements are derived largely from Department of Transportation regulations, which were promulgated to implement the Hazardous Materials Transportation Act. Aspects of the packaging and transportation of radioactive materials are also subject to requirements specified in various DOE orders. Technical requirements (such as cask size, weight, shielding requirements, handling features, etc.) imply a direct link between the development of a transportation system and the waste form technical development program. An integrated systems approach will be used to ensure successful parallel development of waste form fabrication, transportation technologies, and the final repository.

Final waste disposal at a remote repository is the basic assumption underlying development of a transportation system. Since a repository site has not yet been selected, additional assumptions will have to be formulated regarding hypothetical site locations. Nevertheless, considerable information can be obtained from an early analysis of generic transportation options. For example, a detailed analysis of the trade-offs between road and rail transport will help define cask design, canister loading, and production facility design. Once the mode of transportation is defined, conceptual design of shipping casks can proceed in such a way as to minimize diversity in accommodating various waste types. A unified design will be pursueci in order to minimize the expense associated with fabricating casks, and a certification strategy will be developed in parallel with design activities.

\section{FACHITY SUPPORT}

\subsection{Laboratory-scale Tests}

Laboratory-scale testing space is available in existing facilities, CPP-637 for example, though some modifications will be necessary to accommodate SNF handling during testing of SF\&WMTDP technologies. Additionally, laboratory-scale testing will be conducted under contract with various universities.

Laboratory-scale experimentation will involve, but will not be limited to, studies on the effects of varying feed compositions, residence time, pressure, temperature, and throughput variables for each technology. These tests will help (1) determine the feasibility of each process, (2) establish compliance with minimum acceptance criteria, (3) identify and narrow parameter options within a given process, and (4) assist in the design of larger pilot plantscale units. Conceptual design work for pilot-plants needed for the testing of disposal process options will be completed, and title design initiated during the laboratory-scale testing phase of the program.

Each laboratory-scale test entails designing laboratory experiments and equipment, writing specifications for procuring equipment, assembling test systems, developing test plans and 
procedures, performing the studies, and evaluating data. Reports will be issued documenting the results and evaluations from each test.

\subsection{Pilot-plant Tests}

A preliminary analysis of pilot-plant facilities has shown that insufficient space is available for cold pilot-plants and hot cell operations. New pilot plant and hot-testing space in a multifunctional pilot plant facility (MPPF), in addition to existing facilities, will be required to support the proposed research and development work.

Following early testing of various program components, hot verification and full-scale integrated testing will be required. The Test Reactor Area (TRA) may be available for mechanical disassembly component tests and for SNF exam mock-ups. Full-scale cold integrated pilot-plant testing, full-scale mechanical disassembly, and direct disposal could be performed at CPP-637. Hot pilot-plant testing may be performed at several hot facilities, such as the Hot Fuel Examining Facility-North (HFEF-N) at the Argonne National Laboratories-West (ANL-W) and the Test Area North (TAN) Hot Cell (THC) and the Hot Cell Annex. Hot tests for direct-disposal, mechanical disassembly, and hot shredding may require a new hot pilot-plant facility.

Near-term cold pilot-plant space for sodium-bcaring waste testing will require space for sorption column and crown ether extraction column testing, and electro-hydrolysis. Additionally, technologies that may not be amendable to laboratory-scale testing (i.e., freeze crystallization) will be studied at the pilot-scale level. The primary purpose of the pilot-plant test will be to optimize each process technology in addition to defining key scale-up parameters. Cold pilot-plant space will be available at CPP-620 and CPP-637, and long-term hot pilot-plant testing, scheduled to occur after cold pilot-plant testing, may be performed at the HFEF-N cell at ANL-W, or at the FDP facility.

The cold pilot-plant for the calcine immobilization will require space for a mixer, grinder, stabilizer blender/can and fill/compactor, the Hot Isostatic Process (HIP), bulk storage, and transport. Cold pilot spaces will be available at CPP-620, CPP-637, the Technology Divelopment Facility (TDF), and TRA. Near-term hot pilot-plant space will be available at CPP-627 (Multi Curie Cell) for hot stabilization and calcine characterization testing, and pyrochemistry testing may be performed at some of the other INEL hot facilities such as the HFEF-N at ANL-W and the THC and Hot Cell Annex at TAN. Long-term calcine immobilization testing will require a new facility. 


\subsection{Production Complex}

The production complex will condition radioactive wastes for interim storage and final disposition (with the potential of adding SNF conditioning processes in the future) and have a nominal operating life of 30 years. It will be architecturally similar to other ICPP buildings, with human factors being considered in the building's arrangement and function, the placement of equipment, viewing windows, manipulators, instruments, and process controls. The complex will be accessible by major roads within the ICPP to provide for material movements into the facility. Special Nuclear Materials, classified information, and sensitive data at this complex will require protection.

\subsubsection{Complex Design}

The production complex will require numerous hot cells to meet the needs of the final process developed by the SF\&WMTDP. Cell sizes must accommodate full-scale process . installation, have shielding walls sufficient to facilitate the handling of SNF elements and radioactive wastes, and provide for control of entry during and following hot cell activities. Radiation fields outside the cell will be reduced by shielding to meet As Low As Reasonably Achievable (ALARA) and design requirements.

Sample lines originating in each cell and in the process equipment waste tank area will be routed to a sample cell. A pneumatic transfer system from the sample cell to the Remote Analytical Laboratory (RAL) will enable direct delivery of radioactive samples to RAL for analysis.

Mechanical systems will be provided to support operation of the hot work processes. The ventilation system, including process HEPA filters and off-gas systems, will ensure adequate air flow, temperature control, and protection of the environment. Hot-cell ventilation systems will be physically isolated from cold area ventilation systems to preclude crosscontamination.

Control rooms will be equipped with distributed control systems to provide remote operation of pilot-plant modules, utilities, process systems, HVAC systems, and will be capable of handling and transferring materials and tools between cells and to or from the operating corridor. Multiple viewing windows, to allow for the adequate visual coverage of the cell area during remote operations, will be provided in addition to remote handling devices. Cold pilot-plant testing, and subsequent hot testing of new processes leading to process development, will also use remote operation. The conditioning facility would then be used for production with the same remote capabilities.

An overhead crane would be used for removing and replacing hatch covers on each cell and as a means of unloading and loading transfer casks from transport vehicles and positioning them in the crane loft or above cell openings. 


\subsubsection{Complex Construction}

Construction of a production complex will most likely fall under Major System Acquisition (MSA) and, due to the Congressional funding cycle and various required approvals and permits, will take ten years to complete. A project schedule for an MSA usually includes seven to eight years of pre-construction project activities. Actual construction time is generally only $40 \%$ of the total project schedule; but the length of the project may take up to 13 years from the conceptual design phase to start-up.

WINCO has initiated a Scope of Work for Pre-Conceptual Studies for the MPPF Phased Approach and for the Production Complex. These studies will provide cost estimates and schedules for various options. Eight estimates will be provided for stand alone facilities and for existing facilities to house either the MPPF or the Production Complex.

\subsubsection{Complex Operation}

The production complex would receive feed streams from two headend processes (one each for sodium-bearing liquid waste and calcine waste) and use a separation process to separate the feed streams constituents into four product streams, i.e., LLW, HLW, hazardous waste, and non-hazardous nonradioactive products/wastes. Feed streams for the headend process for SNF may be added in the future.

The leading candidates for the separation process are a liquid-liquid process and a halide volatility process. The liquid-liquid separation process would be an extension of the existing ICPP separation techniques, with the Transuranic Extraction (T'RUEX) Process, potentially, being one of the additional liquid-liquid separation processes used for actinide removal. The halide volatility process will use chlorine gas, carbon monoxide, fluorine gas, heat, and electricity to produce chlorides of the feed stream constituents. The chloride products would then be separated by evaporation, condensation, vacuum distillation, and liquid and solid separation steps. Both processes would produce four product streams. The HLW would be ceramified or glassified; the LLW would be grouted; hazardous waste would be drummed and transferred to an appropriate disposal site, and the nonhazardous-nonradioactive products/waste would be recycled, sold, or disposed of in a landfill as appropriate.

\subsection{Environmental Documentation and Permitting Strategies}

If selection of both the integrated testing cancidates and the final process are to occur as scheduled, environmental documentation and permitting for new test facilities and pilot-plants must be initiated as early as possible and, to avoid redundancy or conflict, be coordinated with development of the INEL ER\&WM EIS. Documentation and permitting may require compliance with the National Environmental Policy Act (NEPA); the Resource Conservation and Recovery Act (RCRA) as amended by the FFCA; and the Comprehensive Environmental 
Response, Compensation, and Liability Act (CERCLA), in addition to any other applicable air and water permitting regulations.

WINCO's Waste Management Authority (WMA), formed in January, 1993, to monitor and control the generation of wastes at the ICPP and the Idaho Research Center (IRC), will ensure that the waste streams generated through the SF\&WMTDP are controlled, minimized, and handled in compliance with applicable laws, rules, and regulations.

\subsubsection{NEPA}

As required by NEPA, a pre-evaluation of any new DOE actions must be made to assess what impact, if any, these actions will have on the human environ int. If impact levels are found to be significant, then an Environmental Impact Statement (EIS) must be prepared and a Record of Decision (ROD) published prior to proceeding with proposed activities. Similarly, if the significance is unclear, then an Environmental Assessment (EA) must be prepared to determine significance. If results of the EA indicate the need for an EIS, then an EIS is prepared and appropriate documentation published. If, however, an EIS is not required, a Finding of No Significant Impact (FONSI) document is issued and activities proceed as proposed. Activities whose impact is clearly insignificant are categorically excluded (CX) from the need to prepare either an EA or an EIS.

Current testing and development activities are being conducted in existing facilities within the bounds of their existing NEPA documentation. New activities proposed to be conducted in CPP-637/620 have been evaluated in an Environmental Checklist (DOE Form ID F5440.1A, Rev, 8/90) that has been reviewed by WINCO NEPA personnel. The WINCO NEPA representative, consequently, has recommended to DOE that the activities proposed in the Environmental Checklist be categorically excluded (as defined in 40CFR1508.4) and that DOE issue a Categorical Exclusion Determination. Other activities, involving new facilities, facility modifications, or processes and emissions that are outside the bounds of existing NEPA documentation will require additional Environmental Checklists to determine the appropriate level of NEPA documentation required.

NEPA requires that evaluation of proposed activities for significance be completed and an EIS with a ROD or an EA with a FONSI be published for any action that is not clearly insignificant before any irretrievable resources are committed to the activity. As a practical matter, DOE implements this requirement by requiring either a Categorical Exclusion Determination, or an approved NEPA document (EA with FONSI, or EIS with ROD) before starting Title II design or purchase of materials. A schematic diagram of the NEPA process is presented in Figure 10. 


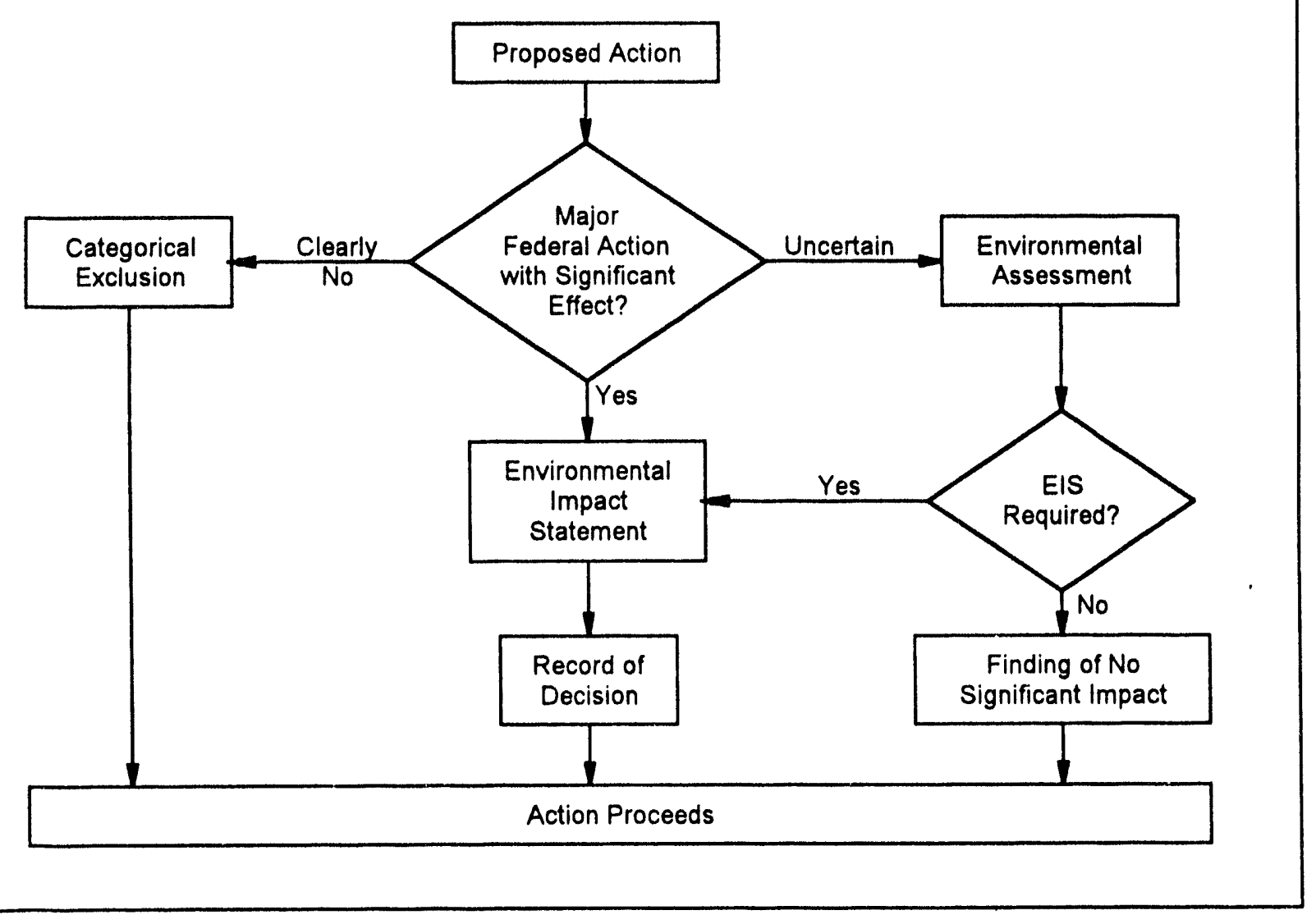

Figure 10: NEPA Documentation Process

\subsubsection{RCRA}

The Resource Conservation and Recovery Act (RCRA) of 1976 ensures the environmentally sound management of solid wastes to (1) protect human health and the environment, (2) reduce waste and conserve energy and natural resources, and (3) reduce or eliminate the generation of hazardous waste as expeditiously as possible. Under RCRA, permits (Part A or Part B) must be obtained to generate, transport, treat, store, and dispose of hazardous . and/or radioactive mixed waste (RMW).

In 1988, INEL completed part A of the RCRA Treatment, Storage, and Disposal (TSD) permit application and was granted Interim Status. Under Interim Status, a facility is restricted to employing processes and operating within facility design capacities to treat, store, or dispose of wastes only as specified in Part A of the permit application. Since that time, ICPP has been required to operate its TSD facilities according to the RCRA Interirs. Status regulations outlined in 40CFR265/270. Part B permit applications, for various facilities, are currently being prepared by INEL personnel. 
Additionally, areas at the ICPP used to perform research, development, and demonstration (RD\&D) on mixed waste streams, such as calcine, will require a RCRA RD\&D permit under 40CFR 270.65. Alternatively, research using hazardous waste can be done under a treatability study exclusion. RCRA RD\&D permit applications are currently being prepared for Laser Ablation, LLW Cementation, Calcine Immobilization, and Sodium-waste Stabilization technology development, as well as for the construction and operation of the Multi-functional Pilot Plant Facility (MPPF).

RCRA also requires that final waste forms generated from radioactive waste conditioning processes meet Land Disposal Restrictions (LDR). LDR, as stated in the Hazardous and Solid Waste Amendments to RCRA, restricts the land disposal of certain hazardous wastes beyond specified dates unless the wastes are treated with the best demonstrated available technology (BDAT). Upon selection of a final waste management technology, as described in section 3.6 of this document, that technology will be submitted to the Environmental Protection Agency (EPA) for certification as BDAT.

The Federal Facilities Compliance Act (FFCA) of 1992 waives sovereign immunity for Federal Government facilities with respect to substantive and procedural requirements including fines and penalties as a result of violations of the Solid Waste Act, as amended by RCRA. The effective date of waiver is delayed for three years with respect to 3004 (j) storage violations "so long as the waste is managed in compliance with all applicable requirements." DOE will have the three year delay of waiver and may submit a compliance plan that, if approved by the State of Idaho, will continue to exempt DOE from the waiver as long as they are in compliance with the plan.

The Solid Waste Act requires DOE to submit plans for developing treatment for wastes, regardless of the time they were generated. Plans shall contain: (1) a schedule for submission of all permits, (2) construction, (3) systems testing, (4) commencement of operations, and (5) processing of backlog waste. For wastes that have no identified treatment DOE shall submit a schedule for identifying treatments and developing treatments including funding requirements.

A schedule and supporting text detailing the SF\&WMTDP will be integrated into the Conceptual Site Treatment Plan, which will be transmitted to DOE-ID for submission to the State of Idaho per the DOE-HQ April 6, 1993, Federal Register Notice. This information will be updated to reflect current developments and integrated with the Draft and Final Site Treatment Plans in compliance with the Act.

\subsubsection{CERCLA}

The Comprehensive Environmental Response, Compensation, and Liahility Act (CERCLA), passed by Congress in 1980, addresses (1) environmental problems resulting from past practices and (2) environmental emergencies caused by the release of hazardous substances. CERCLA gives the federal government authority to respond to releases or the threat of 
releases of hazardous substances that may present an imminent or substantial danger to public health and welfare or to the environment. As it applies to the SF\&WMTDP, CERCLA requires that any proposed project or activity be checked against WINCO drawing $\$ 094752$ to see if the proposed action will effect any Environmentally Controlled Areas at ICPP. For those actions falling inside of Environmentally Controlled Areas, proper permits must be obtained prior to commencement of the proposed activities (i.e., excavation permits, etc.).

\subsubsection{Water Permitting}

As required by the State of Idaho and the EPA, any proposed new water discharge must be reviewed for water permitting requirements. For the SF\&WMTDP, each proposed activity must be evaluated and necessary documentation completed for Wastewater Land Application Permit requirements, modifications to sewer lines and potable water mains, and National Pollution Discharge Elimination System permit requirements.

\subsubsection{Air Permitting}

The air permitting program, which is administered by the State of Idaho Division of Environmental Quality (DEQ), ensures that Permit to Construct (PTC) requirements be addressed prior to construction or modification of any stationary source, major facility, or major modification. As it applies to the SF\&WMTDP, PTC requirements must be evaluated for all laboratory testing, pilot plant testing, and final process implementation. If an activity triggers an air permitting requirement (any radiological emissions triggers Prevention of Significant Deterioration (PSD) PTC), the level of significance will determine whether a Below Regulatory Concern (BRC) determination, a PTC, or a PSD PTC is sought from the DEQ.

The National Emission Standards for Hazardous Air Pollutants (NESHAP) Program, regulated by the EPA, has requirements for specific pollutants above designated levels. Proposed activities that have the potential to generate levels above the given limits may be effected by NESHAP and must be evaluated. If the evaluation determines levels above the given limits, a NESHAP application will be prepared.

For the SF\&WMTDP, air permitting will begin by completing an Air Permitting Applicability Questionnaire (APAQ) for any new project. The APAQ is an internal WINCO document available through the Environmental Permitting Group. The APAQ will be used by the Environmental Permitting Group to determine what form of air permitting will be required in order to stay in compliance with the rules and regulations. 


\section{1}
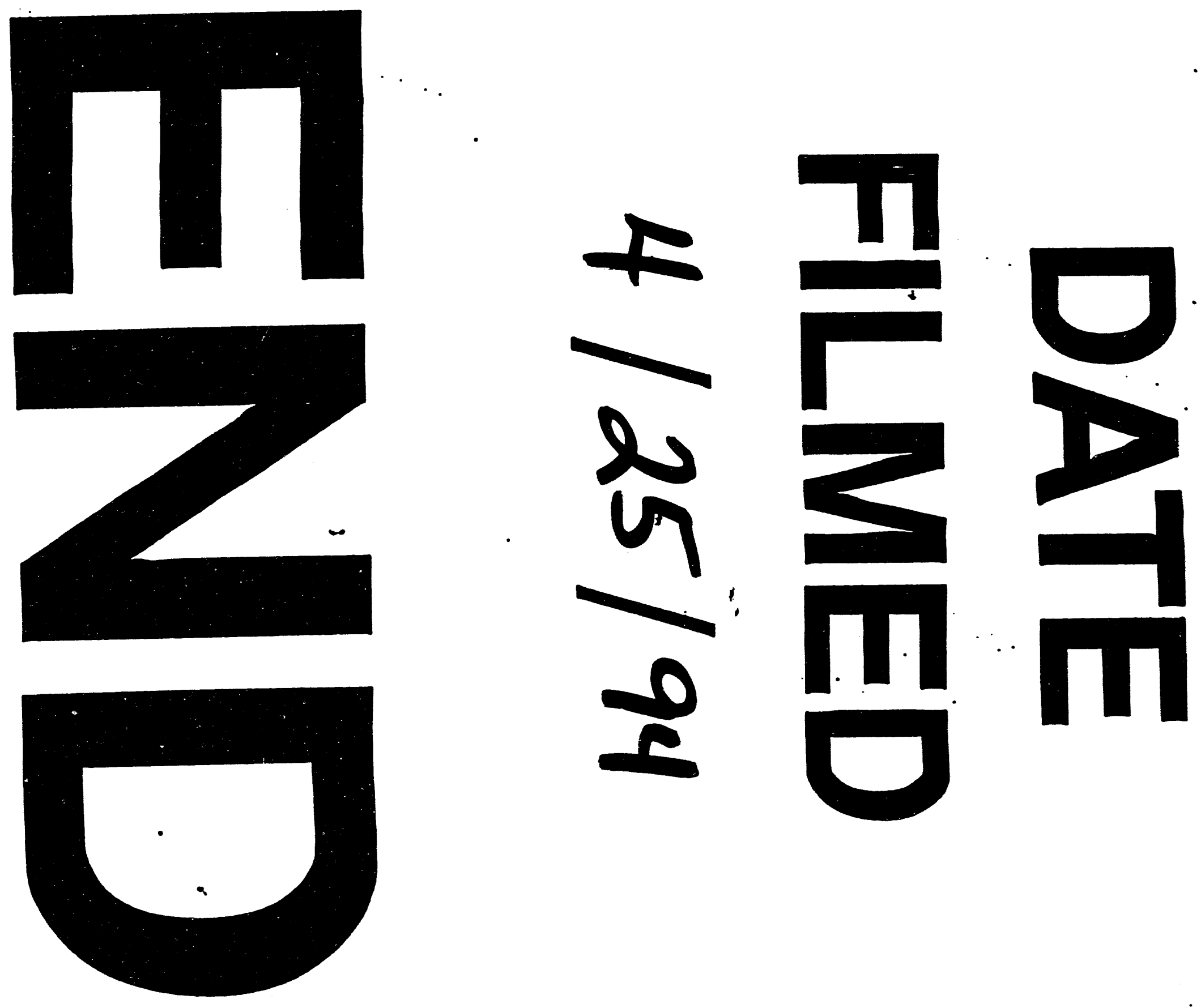


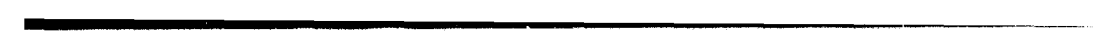

